UII norden

Marine Litter in Nordic waters 

2 norden 



\section{Marine Litter in Nordic waters}

Jakob Strand, Zhanna Tairova, Jóhannis Danielsen, Jens Würgler Hansen, Kerstin Magnusson, Lars-Johan Naustvoll and Thomas Kirk Sørensen 
Marine Litter in Nordic waters

Jakob Strand, Zhanna Tairova, Jóhannis Danielsen, Jens Würgler Hansen, Kerstin Magnusson, Lars-Johan Naustvoll and Thomas Kirk Sørensen

ISBN 978-92-893-4030-4 (PRINT)

ISBN 978-92-893-4031-1 (PDF)

ISBN 978-92-893-4032-8 (EPUB)

http://dx.doi.org/10.6027/TN2015-521

TemaNord 2015:521

ISSN 0908-6692

(C) Nordic Council of Ministers 2015

Layout: Hanne Lebech

Cover photo: Jakob Strand; Kresten Hansen; Søren Kristensen

Print: Rosendahls-Schultz Grafisk

Copies: 200

Printed in Denmark

This publication has been published with financial support by the Nordic Council of Ministers. However, the contents of this publication do not necessarily reflect the views, policies or recommendations of the Nordic Council of Ministers.

www.norden.org/nordpub

\section{Nordic co-operation}

Nordic co-operation is one of the world's most extensive forms of regional collaboration, involving Denmark, Finland, Iceland, Norway, Sweden, and the Faroe Islands, Greenland, and Åland.

Nordic co-operation has firm traditions in politics, the economy, and culture. It plays an important role in European and international collaboration, and aims at creating a strong Nordic community in a strong Europe.

Nordic co-operation seeks to safeguard Nordic and regional interests and principles in the global community. Common Nordic values help the region solidify its position as one of the world's most innovative and competitive.

\section{Nordic Council of Ministers}

Ved Stranden 18

DK-1061 Copenhagen K

Phone (+45) 33960200

www.norden.org 


\section{Contents}

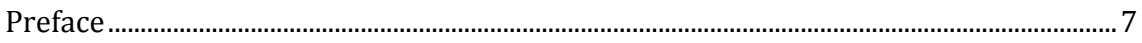

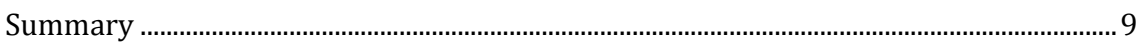

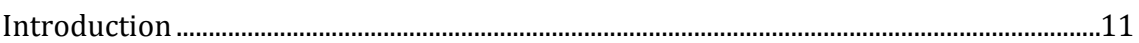

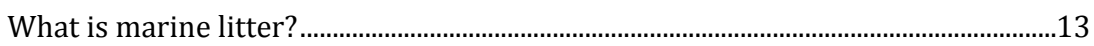

Sources and fate of the marine litter..............................................................................14

Impact of marine litter in the environment ..............................................................18

Marine litter as an environmental indicator................................................................21

1. Overview of studies on macro-litter indicators with emphasis toward

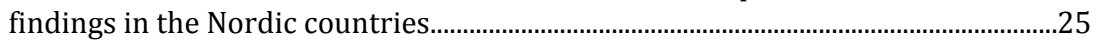

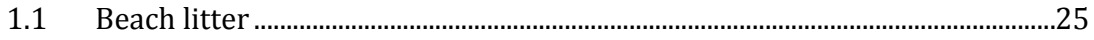

1.2 Macro-litter on the seafloor ................................................................................31

1.3 Macro-litter floating in the water column.........................................................

1.4 Ingestion and impact of macro-litter in biota.....................................................34

2. Overview of studies on micro-litter indicators with emphasis on findings

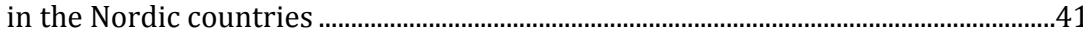

2.1 Microplastic in the water column .......................................................................4

2.2 Microplastics on the beaches and in sub-tidal sediments ..............................46

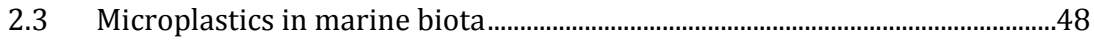

3. Status for management actions on marine litter with relevance for Nordic

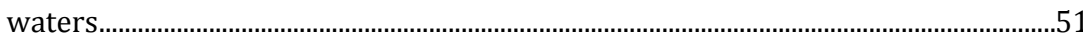

3.1 Current status for implementing Marine Strategy Framework

Directive and national management plans in the Nordic countries.............51

3.2 Status for some international activities related to management of marine litter....................................................................................................55

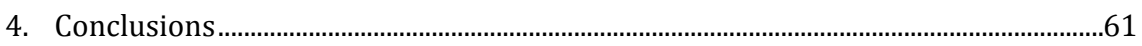

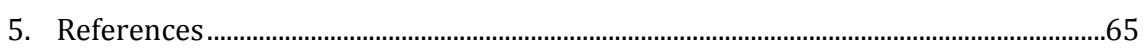

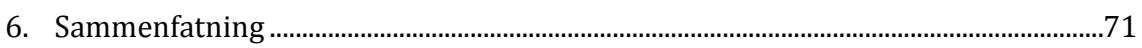

7. Workshop 1 Programme and participants .....................................................................73

8. Workshop 2 Programme and participants ..................................................................75 



\section{Preface}

This report is one of the outcomes of a Nordic project called "Marine litter in the Nordic waters" funded by The Marine Group (HAV) under The Nordic Council of Ministers in 2013-2014.

The main aim of the project was to establish a Nordic forum for collaboration and exchange of knowledge on status for methodologies and available data for marine litter between Nordic experts, environmental managers and stakeholders, due to the common environmental concerns in our shared seas. This report compiles information that can be used as a contribution to facilitate the framing of this environmental problem in a Nordic perspective. This report includes also input from two workshops on I) Common knowledge status on marine litter in the Nordic countries, and indicators relevant for EU Marine Strategy Framework Directive (November 14, 2013 in Gothenburg, Sweden) and II) Status for monitoring and Future actions (November 6-7, 2014 in Oslo, Norway).

The affiliations of the authors are as follows:

- Jakob Strand, ${ }^{1}$ Zhanna Tairova, ${ }^{1}$ Jóhannis Danielsen, ${ }^{2}$ Jens Würgler Hansen, ${ }^{1}$ Kerstin Magnusson, ${ }^{3}$ Lars-Johan Naustvoll ${ }^{4}$ and Thomas Kirk Sørensen. ${ }^{3}$

${ }^{1}$ Aarhus University (Denmark).

${ }^{2}$ Swedish Environmental Research Institute (Sweden).

3 Technical University of Denmark. 



\section{Summary}

In recent years there has been an increased focus on environmental problems arising from litter pollution in the oceans after various studies have described instances of vast amounts of litter including microscopic particles consisting of plastic debris and other synthetic materials. International institutions such as EU, OSPAR, HELCOM and UN have identified marine litter as an important issue that should be prioritized both in terms of knowledge building and the development of environmental indicators that can be used for characterization of the environmental quality. In Europe, marine litter is now high on the environmental agenda, especially after the implementation of the Marine Strategy Framework Directive (MSFD) with obligations for all the EU member states. Subsequently, marine litter has also received increasing attention in the Nordic countries.

In Nordic countries, there has been and are also several on-going field studies, including research, monitoring and other types of surveys. These studies demonstrate ubiquitous occurrence of marine litter in the Baltic Sea, the North Sea and the North Atlantic as well as in the Arctic, where marine litter have been found in all relevant marine compartments, i.e. at beaches, in the water column (incl. sea ice), on the sea floor (incl. in sediments) and in biota.

This report provides an overview of the currently available data from studies on marine litter in the Nordic countries. This covers various field studies on amount, distribution, characteristics and impact of macroand micro-litter particles. The data reported can provide a good basis for prioritisation of activities, especially having the establishment of marine litter indicators for MSFD monitoring and national management plans in the Nordic countries in mind. However, results from the different Nordic studies are not always comparable due to employment of different methodologies for sampling and analyses have been employed. There is therefore a need for a common assemblage of knowledge and experience, and also a standartisation of methods based on the regional conditions that facilitate the framing of this environmental problem in a Nordic perspective. This report compiles information that can be used as a contribution to this process. 



\section{Introduction}

Marine litter, i.e. man-made solid waste in the marine environment, has become a subject of major concern in recent decades, due to the increasing awareness of the widespread occurrence of litter in the marine environment. Globally, huge amounts of man-made solid waste materials end up in the oceans from both land- and sea-based sources. Levels of marine litter are presumed to be rising with the increasing global population densities and industrial production. This is in spite of the fact that better facilities for reception, treatment and disposal facilities for waste have been established in the recent decades, especially in the more industrialized countries.

Plastic waste materials are of special concern, as plastic items are highly persistent and compose the dominating category of marine litter. Plastic debris can pose a risk to the marine environment, by causing physical damage in marine organisms via ingestion or entanglement and also due to potential toxic effects caused by inherent plastic constituents and complex mixture of external contaminants adsorbed onto plastic (Derraik 2002, Rochman et al. 2013).

The widespread and global scale of the distribution of plastic litter together with scientific evidence of potential deleterious effects in marine organisms combined with non-diminishing global plastic production has led to increasing concern among the general public together with national and international authorities like UNEP, EU, OSPAR and HELCOM. Marine litter is now recognized by a wide range of stakeholders as an environmental issue, and is included in for instance the EU Marine Strategy Framework Directive (MSFD 2008/56/EC) as one of the eleven qualitative descriptors which describe what the environment should look like to achieve or maintain good environmental status (GES) in the marine environment by 2020 (European Commission, 2008). However, it has also been recognized that as of today there is only a limited amount of information about the regional differences in sources, levels, composition, fate and impact of marine litter in the marine environment. The Marine Strategy Framework Directive (MSFD) implies establishment of monitoring programmes for assessment, enabling the state and impact of the marine waters to be evaluated on a regular basis. 
Figure 1.1. Clean up activities of marine litter from beaches and other coastlines will often generate large amounts of garbage, which originate from both seabased sources, e.g. ropes and derelict fishing gear, and land-based sources like plastic garbage from recreational activities

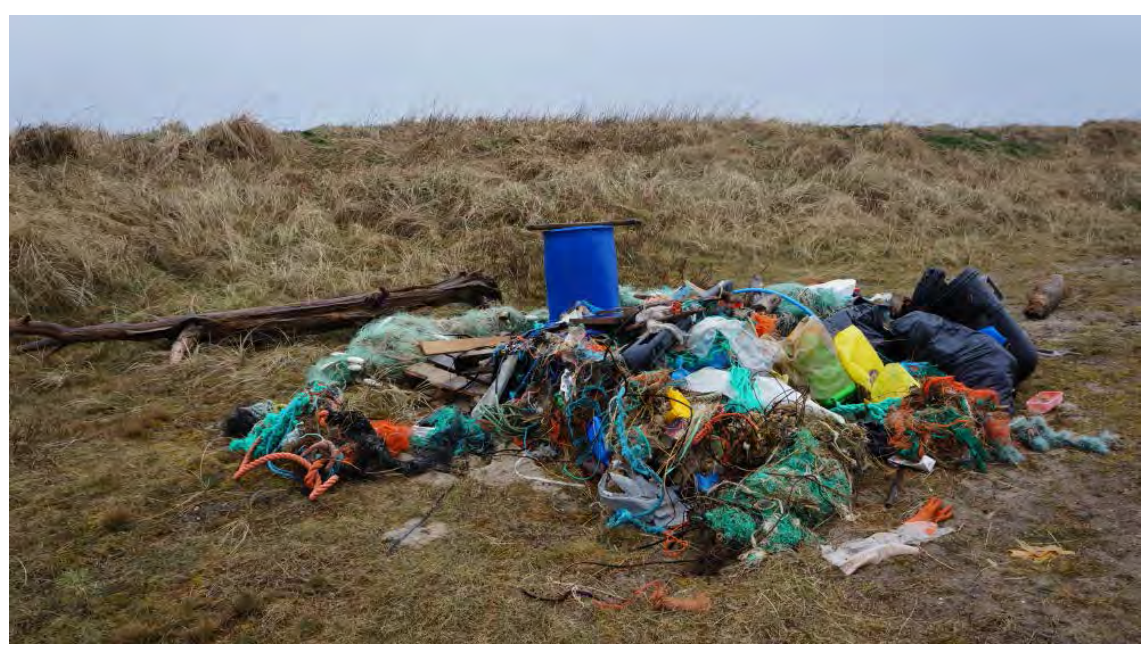

Photo: Jakob Strand, Denmark 2012.

In the Nordic countries various studies on marine litter have been performed, mainly at national levels and within the frames of different types of research projects, environmental monitoring and management and NGO activities. Recently, several marine litter activities have been initiated parallel with the implementation of EU MSFD in Europe and thereby also in some of the Nordic countries, i.e. Sweden, Denmark and Finland. In Norway and Iceland, although not members of EU, national management plans for the marine environment in these countries also include many of the same important elements as in the EU MSFD and also targeting marine litter. For the other Nordic countries that are not EU Member States, i.e. Faroe Islands and Greenland, marine litter can also be relevant for their national marine management plans, although it is not at the moment targeted as a specific element within these plans.

There is therefore a need for the accumulation of knowledge and experience, based on the regional conditions to perceive this environmental problem in a Nordic perspective. Joint collaboration on exchange of knowledge on methodologies, status for monitoring and assessment strategies as well as available data in the Nordic countries is a necessary element in this process.

As an initiative for such an exchange of knowledge in this scientifically fast developing area, this report aims to establish an overview of current research and monitoring activities and available data on marine 
litter in the Nordic countries covering various sea regions, i.e. both in the Baltic Sea, Skagerrak-Kattegat, North Sea, North Atlantic and the Arctic.

This collection of knowledge can act as a contribution to the further process for development of robust and relevant indicators for monitoring and assessment of sources, properties, levels and impact of marine litter in our common seas, both at national, regional and more international levels, and also support the initiated process of developing regional action plans for marine litter both in the North Sea and in the Baltic Sea.

\section{What is marine litter?}

Marine litter is any persistent, manufactured or processed solid material discarded, disposed of or abandoned in the marine and coastal environment (United Nations Environment Programme, 2005). Monitoring studies of marine litter and the beach surveys demonstrate that it comprises of various constituents such as plastics, metals, glass, ceramics, rubber, processed wood, clothing, paper etc. (Aniansson et al. 2007, Cheshire \& Adler, 2009, Galgani et al. 2010). The review of literature and studies on marine litter, also called marine debris, demonstrates that plastic debris comprise most of the marine litter worldwide (Aniansson et al. 2007, Derraik, 2002).

Global plastic production has increased rapidly for the past several decades and was estimated to be 280 million tonnes in 2012 and predicted to become as high as 33 billion tonnes in 2050. It has been estimated that less than half of it was recycled or delivered to landfills. Of the remaining $\sim 150$ million tonnes plastics, some may still be in use or it is has ended as litter in the environment (Rochman et al. 2013).

Marine litter exists as a wide variety of items and particles with multiple shapes and sizes due to diversity of origins. As the size and properties of litter determine their distribution, environmental retention and consequent impact in the environment, it has been necessary to establish a common classification for the marine debris. A master list on nomenclature for different categories of macro-litter items has therefore been compiled in the EU guidance document for monitoring of marine Litter in European seas (Galgani et al. 2013) that can be used for a more harmonised identification of macro-litter items as either washed ashore at beaches, floating in water column, deposited on sea floor or being taken up by marine wildlife. 
For micro-litter, there is still no general consensus about a specific size nomenclature, but there is now a general agreement that it concerns particles $<5 \mathrm{~mm}$ (Galgani et al. 2013). The lower size limit used for identification and quantification of micro-litter particles is still very much dependent on the sampling and processing methods and environmental matrices analysed, and it will therefore often vary between studies (Galgani et al. 2013, Hidalgo-Ruz et al. 2012).

In order to enable the comparison of monitoring results between regions and environmental compartments and to describe the most likely sources it is necessary to implement a common categorization of litter. This is also needed to enhance the assessment of marine litter and related potential harm.

\section{Sources and fate of the marine litter}

Marine litter is entering the sea from many sources, because materials can get lost during production, transport, uses and disposal of the materials. Within the frames of OSPAR Pilot Project on Monitoring waste that ends up as marine litter on beaches in the OSPAR region were identified (Aniansson et al. 2007):

- Fishing, including aquaculture.

- Galley waste (non-operational waste from shipping, fisheries and offshore activities).

- Shipping, including offshore activities (operational waste).

- Sanitary and medical waste (sewage-related waste).

- Public littering (e.g. tourism and other recreational activities).

UNEP has also identified the main sources to marine litter washed ashore on beaches and has divided them into either sea- or land-based sources (UNEP 2005). 


\begin{tabular}{|c|c|}
\hline Main sea-based sources & Main land-based sources \\
\hline Merchant shipping, ferries and cruise liners & Municipal landfills (waste dumps) located on the coast \\
\hline Fishing vessels & $\begin{array}{l}\text { Riverine transport of waste from landfills, etc., along } \\
\text { rivers and other inland waterways }\end{array}$ \\
\hline Military fleets and research vessels & $\begin{array}{l}\text { Discharges of untreated municipal sewage and storm } \\
\text { water (including occasional overflows) }\end{array}$ \\
\hline Pleasure craft & $\begin{array}{l}\text { Industrial facilities (accidental spills, solid waste from } \\
\text { landfills, and untreated waste water) }\end{array}$ \\
\hline Offshore oil and gas platforms & Tourism and other recreational activities at the coast \\
\hline Aquaculture installations & \\
\hline
\end{tabular}

On a global scale, land-based sources are estimated to contribute for some $80 \%$ of marine litter, with the remaining $20 \%$ originating from sea-based sources. This percent relation between sources, however, varies between different regions. A study on land-based sources for litter in the Mediterranean, North and Baltic Seas noted that the landbased sources accounted for $75 \%$ to $90 \%$ of the total number of marine litter items found during the collection of beach litter (Mehlhart \& Blepp 2012). Land-based sources are also predominant, contributing to all of the top ten types of litter found at the Mediterranean region.

The MSFD GES Technical Subgroup on Marine Litter reviews variation in marine litter sources between regional seas (JRC Scientific and Technical Reports 2011). In the Mediterranean, $80 \%$ of the waste was thought to be from land-based sources, mainly related to shoreline and recreational activities. In the southern North Sea shipping, fishery industry and offshore installations were the main sources of litter collected on German and Dutch beaches. In the Baltic Sea main contributing sources for litter vary in different areas of the sea. Tourism and recreational use of the coasts, together with the river fishery and waste dumping were identified as major landbased sources, while commercial shipping and pleasure craft are identified as major sea-based sources for litter in the Baltic Sea.

It is estimated, based on data from the North Sea and the waters around Australia, that $70 \%$ of the marine litter that enters the sea ends up on the seabed, whereas around $15 \%$ is found on coastlines and the last 15\% of the litter is floating on the water surface (UNEP 2005).

Marine litter in the Nordic waters can originate from local, regional sources and global sources because of long-range transport of marine litter with ocean currents. It is well known due to the previous observations and modelling results that marine debris are transported with ocean currents and can occur in greater concentrations in so-called 
"Garbage Patches" within specific regions (Figure 1.2), e.g. in the Pacific, Atlantic and Indian Oceans (Moore 2008, Kaiser 2010).

Figure 1.2. A schematic diagram of the existing five gyres in the world oceans where marine litter accumulates, driven by the ocean currents own production

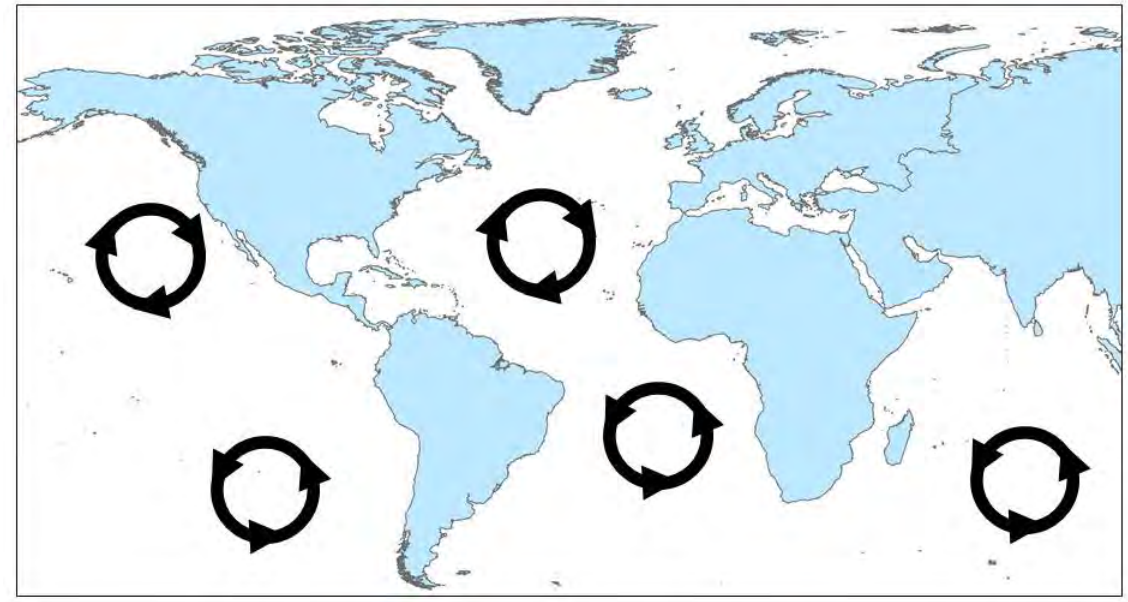

In the Nordic waters, which cover parts of the Arctic, the North Atlantic, the North Sea, the Skagerrak-Kattegat, the Belt Sea and the Baltic Sea, ocean currents are also very important transport factors. For instance, the warm trans-Atlantic surface current reaches the North Sea and Skagerrak en route to the North Atlantic. A part of the North Atlantic current will also continue along the Norwegian west coast towards the Arctic. Thereby long range transport of litter with these ocean currents can potentially result in an accumulation of litter in the Arctic region, for instance in the Barents Sea (Figure 1.3). The residual circulation from the North Sea is also passing along the Norwegian coast after mixing with the outflow from the Baltic and the Skagerrak (Figure 1.4). The shelf currents along the Danish and Norwegian western coasts are predominantly from south to north. This mixing of the currents is creating a local circulation in the Skagerrak region which can function as an accumulation area for the marine litter, including the floating fraction. In addition, the outflow of the low saline water from the Baltic as a surface water layer may also be a minor contributor to marine litter in the Skagerrak. On the other hand, the inflow of the more saline water from the North Sea as a bottom layer into Kattegat and the Belt Sea and the Sound can function as opposite transport routes that can potentially bring marine litter from the North Sea and into the Baltic Sea. 
Figure 1.3. A schematic diagram of the ocean currents from the North Atlantic, supporting the potential of the marine litter to be brought to the Arctic

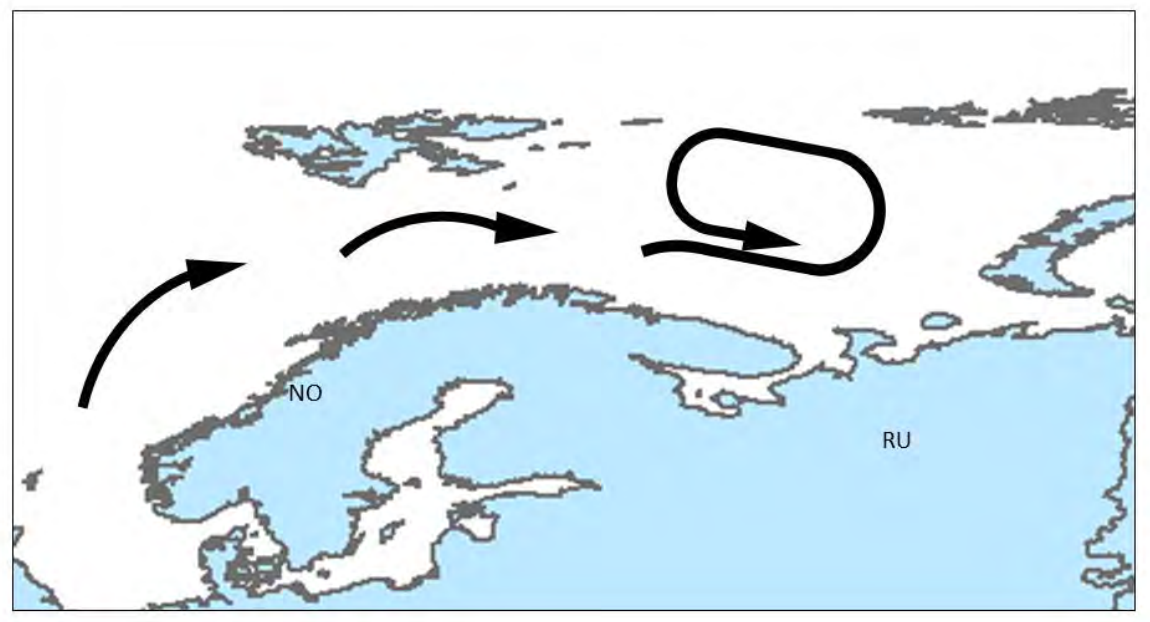

Other hydrographic studies have also shown that large quantities of particulate suspended matter from the southern North Sea are accumulated in the Skagerrak region between Sweden, Norway and Denmark due to the prevailing currents and winds (Eisma \& Kalf, 1987, de Haas et al. 2002). Thus it is very likely that marine litter from the southern North Sea, especially the floating fraction or from resuspended sediments will also tend to end up in Skagerrak. It has been estimated that the coastal areas in Skagerrak receive about $10 \%$ of all marine litter in the North Sea, although they comprise only about $2 \%$ of the total North Sea coastline (UNEP 2005). This is in line with the fact that e.g. the Swedish western shores have experienced very large problems with marine litter for decades (SwAM 2012).

In addition, findings of microplastic in sea ice from the Arctic ocean have indicated that microplastics can accumulate in some areas far from population centers and that polar sea ice could represent a major historic global sink of man-made particulates (Obbard et al. 2014). 
Figure 1.4. A schematic diagram of the general circulation of the ocean currents in the North Sea and Skagerrak, which also include input of Atlantic water Gulf stream currents. Modified from OSPAR 2000

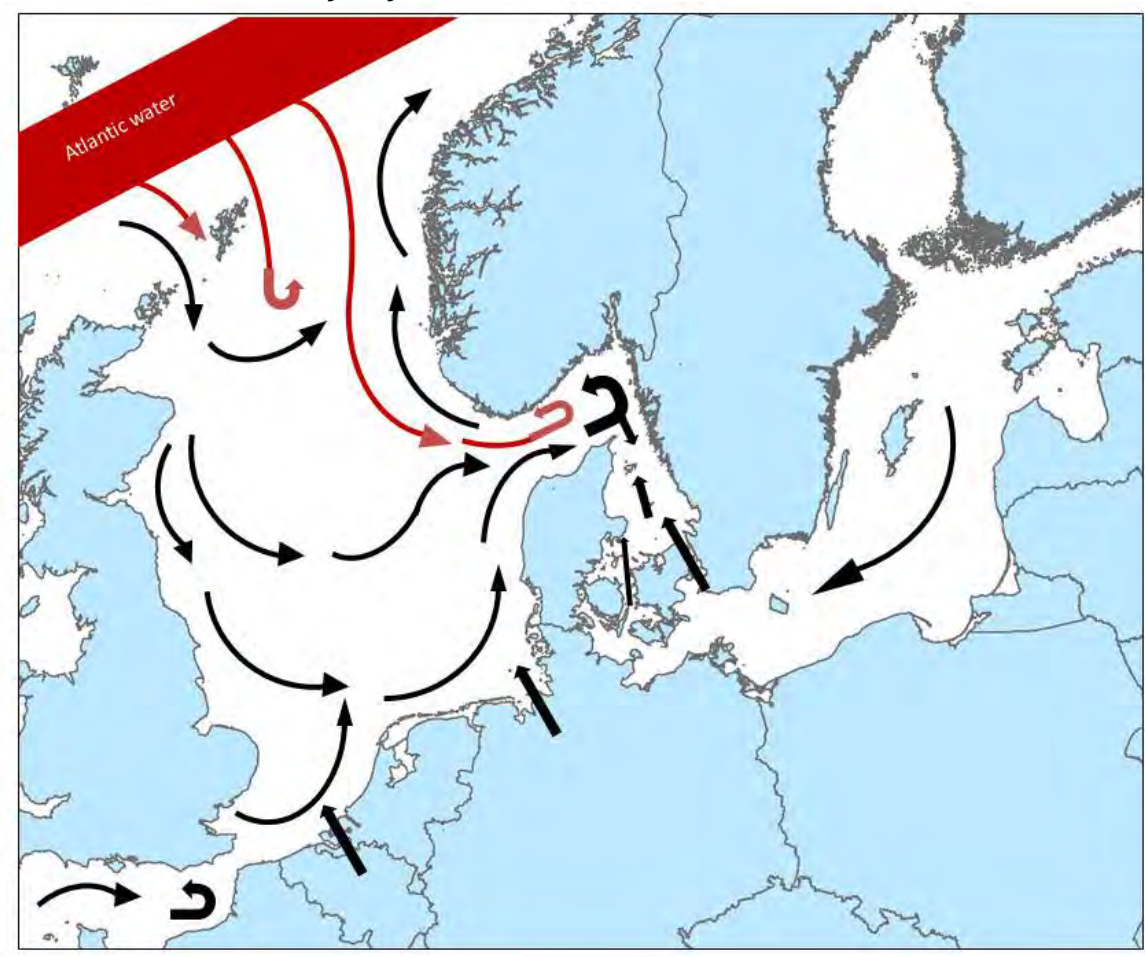

\section{Impact of marine litter in the environment}

The presence of plastic in the marine environment was already noted 40 years ago by e.g. Carpenter et al. (1972) and Colton et al. (1974) who found plastic in fish guts and surface plankton samples.

The UNEP analytical overview of marine litter (United Nations Environment Programme, 2005) states: "Marine litter kills, injures and causes pain and suffering and every year entails great economic costs and losses to people and communities around the world". Whereas some of the negative effects are obvious (e.g. marine safety, aesthetic problems), others, such as effects of plastics ingestion by the wild-life and potential toxicity of the microplastic have only begun to be recognised and studied (Aniansson et al. 2007; Rochman et al. 2013). It has been estimated that plastic debris are the major contributor to marine litter (Aniansson et al. 2007, Derraik, 2002). Being more persistent in nature than most other types of marine litter, plastic pollution poses a serious environmental threat. 
Figure 1.5. Entanglement of the seabird northern gannet in rope-pieces and derelict fishing gear are a relatively common cause of death for this species in the North Sea region

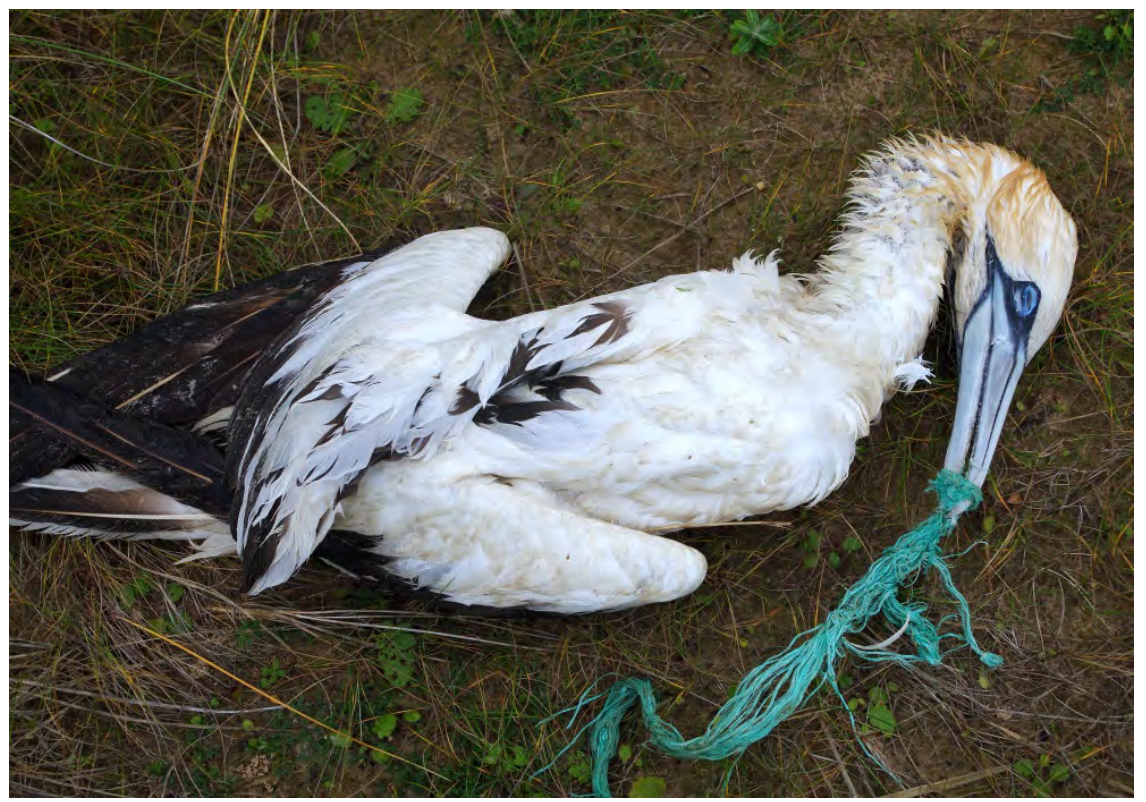

Photo: Kresten Hansen, Denmark 2012.

The potentially harmful effects of marine plastics, both macro- and micro-particles, for the marine ecosystem as well as humans can mainly be grouped into following four categories:

- Ingestion and entanglement of wildlife.

- Source and vector for contaminants in marine waters.

- Spreading of non-indigenous species and pathogens.

- Socio-economic effects.

Ingestion and entanglement of wildlife, e.g. sea birds, mammals, are clear and visible evidences of the severe effects that marine litter can have in the marine ecosystem.

More susceptible are the potential risks of ingested macro- and micro- plastics that can act as a source to toxic plastic constituents or as a vector for other hydrophobic contaminants occurring in the environment and which can be absorbed into the plastic from the surroundings. The ingestion of microplastics, which has been demonstrated in a range of marine organisms may facilitate the transfer of toxic compounds, i.e. inherent contaminants, e.g. plastic additives, leaching from the plastic 
material, or extraneous lipophilic pollutants, adhered to the plastic material from the environmental matrices and disassociating into organisms' tissues (Browne et al. 2008; Cole et al. 2011).

Similar impacts may apply for plastic constituents, i.e. plasticisers and degradation products from polymers that are the compounds incorporated into plastics during manufacture in order to change their properties and/or extend the life span of the plastic by providing resistance to heat, oxidative damage and microbial degradation (Cole et al. 2011). Some of these additives (e.g. phthalates, bisphenol A, alkylphenols and polybrominated flame retardants) are of health and environmental concern since they are potential carcinogens and endocrine disruptors and can leach out of ingested plastic particles, introducing potentially hazardous chemicals into the organism.

In the environment, hydrophobic contaminants like organochlorines, PAHs, etc will associate with organic matter. In this respect, man-made synthetic particles like plastics have comparable properties with naturally occuring organic matter.

Studies have indicated that plastic particles in sediments may be an important source for some hydrophobic organic contaminants like PAHs, as plastics were shown to have greater affinity for PAH compared with natural sediments and also that addition of small amounts of contaminated microplastics increase accumulation of PAHs in the sediment dwelling organisms (Teuten et al. 2007, Teuten et al. 2009). Another example on significant transfer of plastic-derived/-associated chemicals to biota is from a Japanese study on seabirds finding generally higher levels of brominated flame retardants in tissues from the birds when also the plastic isolated from their stomachs contained high levels of these compounds (Tanaka et al. 2013). It has also been raised that the accumulation of plasticisers like phthalates in Mediterranean cetaceans can be associated with the potential intake of plastic particles by water filtering and plankton ingestion (Fossi et al. 2012).

Marine litter can act as carrier for exotic species from other continents, and thereby be a potential route for introducing non-indigenous species. Pelagic plastic items floating in the oceans are commonly colonized by various species like bryozoans, barnacles, tube worms, foraminifera, coralline algae, hydroids and bivalve molluscs, and in between also species mainly occurring in the tidal zones. Potentially, dispersal of aggressive alien and invasive species by these mechanisms could endanger sensitive, or at-risk coastal environments (both marine and terrestrial) far from their native habitats (Gregory 2009). 
Another biological problem may rise from that litter items in the aquatic environments also will be covered by biofilm consisting of complex microbial communties (Hoellein et al. 2014). Potentially, marine litter can thereby also be carriers of harmful pathogens and bacteria from local point sources like waste water treatment plants or medical waste or from long range transport across the oceans. For instance a study on microbial communities on plastic items floating in the North Atlantic showed that the communities were distinct from the communities in the surrounding surface water, implying that plastic serves as a novel ecological habitat in the open ocean. It was indicated that plastic items also could act as carriers of opportunistic pathogens, because microbes of genus Vibrio dominated on one of the analysed plastic samples (Zetler et al. 2013).

Regarding the socio-economic effects of marine litter, they can be grouped into a number of general categories: damage to the installations and equipment used at sea (e.g. fishing boats and gear, cooling water intakes in power stations), contamination of beaches, harbours and marinas, contamination of coastal grazing land, causing injury to livestock, safety risks at sea (e.g. fouling of propellers), potential cause of health issues (injuries, disease) from litter on beaches and in bathing water, including medical waste.

\section{Marine litter as an environmental indicator}

It has been recognised that a number of related indicators are needed for assessing state and impact of marine litter depending on the marine compartment to be assessed, i.e. shores, water column, sea floor and biota (JRC 2011). Such indicators are therefore also recognised in the MSFD, which aims to establish a framework within the EU, so the member states can take measures to achieve or maintain good environmental status (GES) in the marine environment by 2020.

One of the eleven qualitative descriptors for determining GES, "Descriptor 10", within the MSFD is: "Properties and quantities of marine litter do not cause harm to the coastal and marine environment" (European Commission, 2010). There are two criteria concerning characteristics and impacts of marine litter under descriptor 10, and four general indicators for marine litter are described (Table 1.1). 
Table 1.1. Criteria and indicators for marine litter in Descriptor 10 from MSFD (European Commission, 2010)

\begin{tabular}{ll}
$\begin{array}{l}\text { Criteria 1: } \\
\text { Characteristics of litter in the marine and coastal } \\
\text { environment }\end{array}$ & $\begin{array}{l}\text { Criteria 2: } \\
\text { Impacts of litter on marine life }\end{array}$ \\
$\begin{array}{l}\text { GES Indicators: } \\
\text { Amount, composition, spatial distribution and where } \\
\text { possible the source of: }\end{array}$ & $\begin{array}{l}\text { GES Indicators: } \\
\text { Amount and composition of: } \\
\text {-Litter washed ashore and/or deposited on } \\
\text { coastlines }\end{array}$ \\
$\begin{array}{l}\text {-Litter in the water column (including floating at the } \\
\text { analysis) }\end{array}$ \\
$\begin{array}{l}\text { surface) and deposited on the seafloor } \\
\text {-Micro-particles (in particular micro- plastics) }\end{array}$ & $\begin{array}{l}\text { However, it needs to be developed further, based } \\
\text { on the experience in some sub-regions and } \\
\text { adapted in other regions }\end{array}$ \\
\hline
\end{tabular}

The methodologies used for achieving data for the different GES indicators will generally fall into one of the following basic types (Maes \& Garnacho 2013.

Beach litter surveys, which include:

- Collection of litter on shorelines (100 m or $1 \mathrm{~km}$ streches).

Seafloor litter surveys, which include:

- Observations made by divers, submersibles or camera tows (ROVs).

- Collection of litter via benthic trawls.

Floating litter surveys, which include:

- Observations (visual/camera) made from ship or aerial based platforms.

- Collection of litter via surface trawls.

- Plastic ingestion by seabirds, fulmar (suggested recently by OSPAR).

Biota surveys of ingested litter or entanglement, which include:

- Birds

- Mammals

- Fish

- Other (e.g. turtles).

- Surveys of micro-litter

- Sediments (subtidal/tidal/Beaches) 
- Water (Surface/Suspended)

- Biota (Invertebrates/fish).

HELCOM (HELCOM CORESET 2014) and OSPAR (OSPAR 2014b; T. Maes $\&$ J. Mouat, pers. comm.) are currently in the process of developing a set of regional marine litter indicators targeting the different GES indicators in MSFD, so they can be recommended common or candidate indicators for the Baltic Sea and North-East Atlantic (including the North Sea), respectively (Table 1.2).

Table 1.2. Specific marine litter indicators currently in the process of being recommended by HELCOM (HELCOM CORESET 2014) and OSPAR (OSPAR 2014b, Maes, pers. comm.) as indicators for the Baltic Sea and North-East Atlantic, respectively. The status of the indicators as common or candidate indicators in the current process of developing a set of regional marine litter indicators is also included as presented at the $2^{\text {nd }}$ Nordic workshop "Marine litter-monitoring and management in the Nordic context", 6-7 November 2014

\begin{tabular}{lll} 
Marine litter indicators & OSPAR & HELCOM \\
$\begin{array}{l}\text { Litter washed ashore and/or deposited on } \\
\text { coastlines }\end{array}$ & $\begin{array}{l}\text { Beach litter } \\
\text { (Common indicator) }\end{array}$ & $\begin{array}{l}\text { Beach litter } \\
\text { (Candidate indicator) }\end{array}$ \\
$\begin{array}{l}\text { Litter in the water column (including } \\
\text { floating at the surface) }\end{array}$ & $\begin{array}{l}\text { Plastic particles in stomachs of fulmars } \\
\text { (Common indicator for the North Sea) }\end{array}$ & - \\
Litter deposited on the sea-floor & $\begin{array}{l}\text { Seabed litter using International } \\
\text { Bottom Trawl Surveys (IBTS) } \\
\text { (Prioritized candidate indicator) }\end{array}$ & $\begin{array}{l}\text { Seabed litter using Bottom } \\
\text { (Candidate indicator) }\end{array}$ \\
$\begin{array}{lll}\text { Micro-litter } \\
\text { (in particular microplastics) }\end{array}$ & $\begin{array}{l}\text { Microplastics, methodology currently } \\
\text { not defined, R\&D still needed } \\
\text { (Candidate indicator) }\end{array}$ & $\begin{array}{l}\text { Microplastics in water } \\
\text { column (sediment also } \\
\text { considered) } \\
\text { (Candidate Indicator) }\end{array}$ \\
Litter ingested by marine animals & $\begin{array}{l}\text { Plastic particles in stomachs of fulmars } \\
\text { (Common indicator for the North Sea) }\end{array}$ & \begin{tabular}{l} 
- \\
\hline
\end{tabular} \\
\hline
\end{tabular}

It should be noticed that OSPAR is considering plastic particles in stomachs of fulmars to be an indicator for both floating litter and impact on biota in the North Sea area. In addition, both OSPAR and HELCOM are considering other target species/impact on biota indicators than plastic particles in stomachs of fulmars, so this GES indicator also can be assessed in other sea areas than the North Sea, North Atlantic and the Arctic.

The overall target for the MSFD indicators for GES has been defined as "decreasing trends in amounts of litter items". OSPAR has in addition, also proposed a more specific target for marine litter in biota, as the Ecological Quality Objective (EcoQO) based on weight of plastic in stomach of sea bird fulmars (OSPAR 2012, OSPAR 2014b). 
Regarding defining baselines and assessments of temporal trends, it has been proposed to use running 6 years average on the relevant marine litter indicators by OSPAR and HELCOM (T. Maes \& J. Mouat, pers. comm., HELCOM CORESET 2014b).

National authorities of EU countries are still in the process of providing more concrete developments and implementation for the specific indicators and targets for marine litter implementation of the MSFD descriptor 10 and the establishment of appropriate monitoring strategies and management plans and measures, which also need regional adjustments.

The development of initial assessments for MSFD by each EU member state in 2012 and corresponding national assessments by some none-EU member states, e.g. Norway, has been one of the first steps in this process. Secondly, most Nordic countries have in 2014 described their plans for monitoring different marine litter indicators in the coming years, see Chapter 4.

During the last couple of years, monitoring activities and several recent studies, also in Nordic waters, have provided new knowledge on the amount, composition and spatial distribution of marine litter in the sea. The ongoing and future studies will also provide new information in the coming years. Therefore there is still a need for compiling current knowledge and experience about the occurrence, fate and impact of marine litter and methodologies for improving environmental monitoring and assessments in our region. 


\section{Overview of studies on macro-litter indicators with emphasis toward findings in the Nordic countries}

One of the clearly visible signs of litter in the marine environment that first comes to mind is the macro-litter items washed ashore from the sea and deposited on the shore lines. Fishermen working at sea will often also often recognise macro-litter items when garbage appears in their net after trawling in the water column or on the sea floor. Evidence of the widespread marine pollution with macro-litter will also appear in many other contexts like in surveys for maintenance of constructions and pipelines along the sea floor or in studies on stomach contents in marine wildlife like fish, seabirds or mammals.

Subsequently, different data sources for the marine litter indicators have potential to be used for describing amounts, composition, spatial distribution and temporal trends of macro-litter in the sea.

\subsection{Beach litter}

Registration of amounts and composition of marine litter washed ashore on beaches has been performed in almost all Nordic countries, either as part of systematic monitoring activities or as part of less consistent coastal clean-up activities organised by for instance local communities or NGOs. The data from these campaigns are often based on total amounts of marine litter items as e.g. total weight or number of waste bags filled. Results of such clean-up activities have the potential to be used to support indicators to detect changes resulting from management actions combatting litter in the marine environment

A more consistent monitoring with more detailed registration of amounts and composition of marine litter items on reference beaches is required if trends should be adequately assessed. Such monitoring activities were initiated in the North Sea and Skagerrak in Sweden, Denmark 
and Faroe Islands in 2001-2002 as part of the EU funded project called "Save the North Sea". Comparable guidelines for both $100 \mathrm{~m}$ stretches and/or $1 \mathrm{~km}$ stretches have been followed for registration of amounts and composition of marine litter items, which corresponds to the OSPAR guidelines for monitoring marine litter on the beaches (OSPAR 2010). Sweden and to a minor extent Denmark has continued monitoring at these reference beaches on a yearly basis and up to 3 times per year, and data have been reported to the OSPAR Beach Litter Database (http://www.mcsuk.org/ospar/). Norway has also recently reported data for marine litter from beaches in the North Sea/Skagerrak region as well as from the Arctic (OSPAR database 2014).

In the Baltic Sea, several beaches from Sweden, Finland and other Baltic states have been systematically monitored in 2012 - 2014 as part of the EU-funded project called "MARLIN" (http://www.projectmarlin.eu/). The monitoring was done according to the UNEP guidelines on survey and monitoring of marine litter (UNEP 2009), although adapted to Baltic Sea conditions (HSR 2014).

When comparing regional median-values for the Nordic monitoring data in the OSPAR database with the MARLIN data from the Baltic Sea, a clear tendency on the differences between the different marine regions can be seen (Figure 2.1). The highest numbers of beached litter items are generally found on $100 \mathrm{~m}$ stretches of coastlines occurring in the Skagerrak region followed by the eastern North Sea, supporting the fact that this region is an important sink for marine litter from the southern North Sea. The lowest levels are generally found on beaches in the Baltic Sea followed by beaches in the Arctic and the North Atlantic. However, some very high numbers of marine litter items can also be found at some beaches in the Arctic, especially at Svalbard, supporting observations that huge amounts of marine litter are transported with ocean currents towards this region, and that local hydrographic conditions can reveal a high deposition of marine litter on some Arctic shorelines. 
Figure 2.1. Regional comparison of number of beached litter items found on 100 $m$ streches of coastlines show that the largest amounts in Nordic waters generally occur at the Swedish and Danish west coasts (Based on OSPAR + MARLIN data 2002-2012).The figure shows box whisker plots with median, 10th, 90th, minimum and maximum-values per region on a logarithmic scale. The red dotted line connects the regional median values

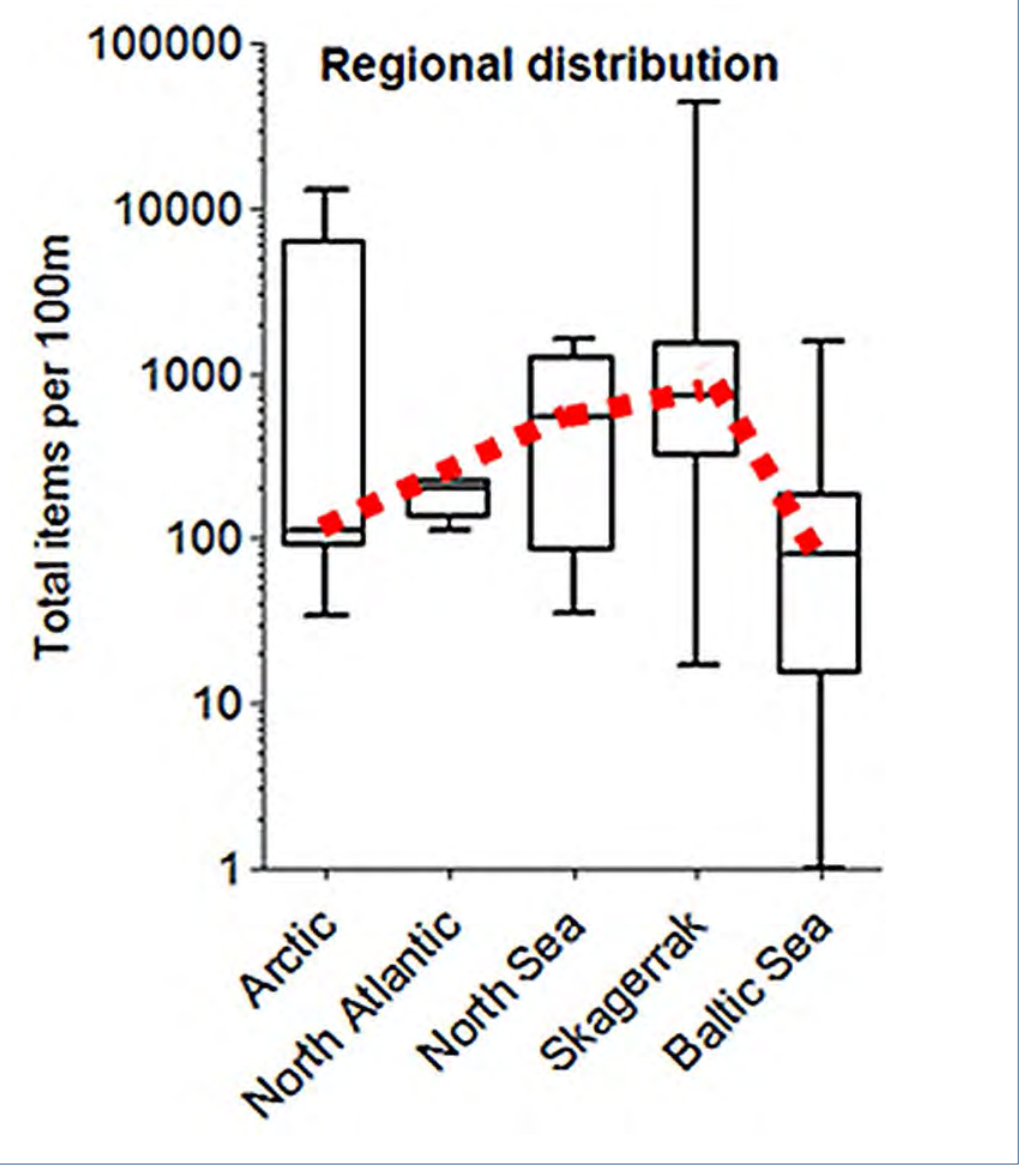

Regarding the composition of the marine litter items found on the Nordic beaches, some tendencies in regional differences can also be found using the general OSPAR categories for grouping marine litter items (Figure 2.2). By comparing the regional median-values it seems that the contribution of plastic/polystyrene items increases from the Baltic Sea $(62 \%)$ to Skagerrak $(76 \%)$ and the eastern North Sea $(71 \%)$ and further more towards the North Atlantic (88\%) and the Arctic (97\%), that may indicate that especially plastic items will be transported over long distances with ocean currents. The regional patterns relating to the contribution from the other categories for marine litter items are more comparable although there are a few exceptions. Solid pollution, mainly as 
wax, is more frequently occurring in the North Sea, probably due to intense shipping traffic and/or offshore activities. Sanitary waste is more frequently occurring in the Skagerrak, especially at one Danish station, indicating poor handling of waste water in that particular area, but it should also be noticed that these findings are from 2003-2005, i.e. they are not recent observations.

Figure 2.2. Regional comparisons of the amounts and composition of marine litter items found on 100 m stretches of coastlines show that plastic/polystyrene items are the dominant contributor to litter in all parts of the Nordic waters

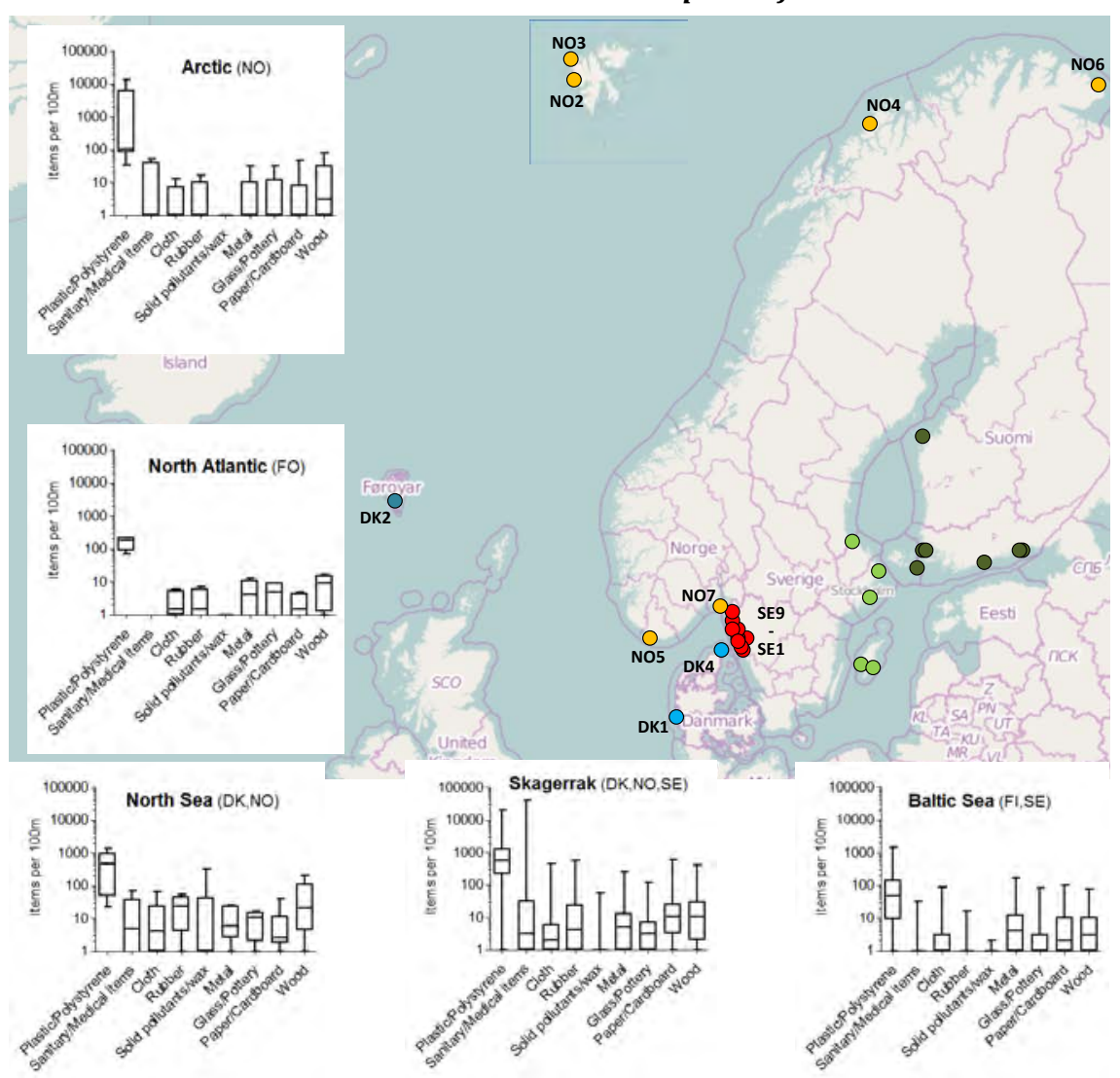

The Nordic monitoring stations are shown as circles with different colours for each Nordic country, i.e. Denmark (blue), Swedish west coast (red), Swedish east coast (green), Norway (orange) and Finland (grey).

Based on OSPAR + MARLIN data 2002-2012, where MARLIN data has been translated to the general OSPAR categories using the EU master list.

Recently, EUs Environmental Agency (EEA) has developed a mobile app called "Marine Litter Watch" for collecting data on marine litter on beaches relevant for the MSFD to support official monitoring (EEA 
2014). This is in line with EU Guidance on Monitoring of Marine Litter in European Seas (EU 2013). This mobile app facilitates the collection of data with the help of interested citizens and communities for instance from clean-up operations as well as from more systematic monitoring activities. In 2014, there has been reported marine litter data from several beaches in the Nordic countries including Denmark, Sweden, Norway, and Iceland. However, it is not fully clear to what extent the sampling and registration of all the Nordic data in the EEA database are performed in agreement with EUs recommended monitoring guidelines, because much of the data has been generated from NGO-led beach clean ups, where the main objective has been to raise public awareness for problems related to marine litter.

It is worth mentioning that although these methodologies for collecting and registration of marine litter items described in the OSPAR, UNEP or EU guidelines are quite similar, there are also some minor discrepancies to be aware of, for instance:

- The number of sampling campaigns during the year may vary, although preferably 4 times per year are recommended according to the international guidelines from UNEP (2009), OSPAR (2010), and EU (2013). In most Nordic countries sampling cannot be performed during winter and therefore 3 times per year is generally accepted.

- The length of the segment of the coastline to be sampled can vary: The normal range is $100 \mathrm{~m}$ stretches for collecting litter $>2.5 \mathrm{~cm}$, although at some beaches $1 \mathrm{~km}$ stretches are additionally monitored with collection of litter $>50 \mathrm{~cm}$. It should also be noticed that the length of monitored stretches can vary for data reported using EEAs app "Marine Litter Watch", since the length from start to end is determined by the use of GPS positioning.

- The type of beaches to be sampled can vary. The OSPAR guidelines recommend monitoring at only so-called reference beaches with minor impact of human beach activities, whereas UNEP and EU guidelines (defines) recommends that monitoring is carried out at $\mathrm{A}$ ) Urban coasts (i.e. mostly terrestrial inputs), B) Rural coasts (i.e. mostly oceanic inputs) and C) Coasts within close distance to major riverine inputs.

- Categorizations of different types of marine litter items may differ between guidelines used. The OSPAR and UNEP guidelines have originally developed their own lists for identification and registration of marine litter items, and subsequently resulting in some minor 
discrepancies between the categories defined. Recently, EU has developed a Master list of categories of litter items (EU 2013), which include codes from both the OSPAR and UNEP lists as well as few additional codes. The Master List includes also corresponding codes from the OSPAR and UNEP lists, when applicable. The indicator items such as those used in the OSPAR, UNEP or in the Master List for codes on different marine litter categories can to some extent be linked to potential sources and pathways, e.g. fishery, sanitary waste, industry or public littering.

An overview of the Nordic surveys with more systematic and consistent monitoring data on beach litter, i.e. from the OSPAR database and the MARLIN project in the Baltic Sea, is given in Table 2.1 together public clean-up activities with data mentioned in the reports for the initial MSFD assessments from Denmark (NST 2012) and Sweden (SwAM 2012) or in the national report on status for marine litter in Norway (KLIF 2011).

Table 2.1. List of Nordic surveys on beach litter with data available in the OSPAR database, MARLIN project in the Baltic Sea or surveys with data from public clean up activities mentioned in the reports for the initial MSFD assessments from Denmark (NST 2012) and Sweden (SWAM 2012) or in the national report on status for marine litter in Norway (KLIF 2011)

\begin{tabular}{|c|c|c|c|c|}
\hline Type, Method & Sea region & Country & Years & References \\
\hline \multirow[t]{7}{*}{$\begin{array}{l}\text { Beach litter } \\
\text { surveys }\end{array}$} & NA, SK, NS & NO & 2011-2012 & $\begin{array}{l}\text { OSPAR database } \\
\text { (2014), KLIF (2011) }\end{array}$ \\
\hline & SK & SE & 2001-2012 & $\begin{array}{l}\text { OSPAR database } \\
\text { (2014), SwAM (2012) }\end{array}$ \\
\hline & NA & FO & $2002-2006$ & OSPAR database (2014) \\
\hline & NS, SK & DK & 2002-2012 & $\begin{array}{l}\text { OSPAR database } \\
\text { (2014), NST (2012) }\end{array}$ \\
\hline & BS & $\mathrm{SE}, \mathrm{FI}$ & 2012-2014 & MARLIN (2014) \\
\hline & BS, SK & SE & $\begin{array}{l}\text { 2010-2011 } \\
\text { (Stada Sverige) }\end{array}$ & SwAM (2012) \\
\hline & NA & NO & $\begin{array}{l}\text { 1979-2010 } \\
\text { (Sør-Trøndelag) }\end{array}$ & KLIF (2011) \\
\hline
\end{tabular}

Sea regions: Baltic Sea (BS), Skagerrak-Kattegat (SK), North Sea (NS), North Atlantic and Artic (NA). Countries: Denmark (DK), Norway (NO), Faroe Islands (FO), Finland (FI), Sweden (SE). 


\subsection{Macro-litter on the seafloor}

There have in the Nordic countries been performed different types of activities regarding marine macro-litter on the sea-floor. Some data exist for bottom trawl catches, e.g. by registration of fishermen's catches "Fishing for litter" and registration from bottom trawl surveys for stock assessments of demersal fish species in the Baltic Sea (BITS) or in the North Sea and North Atlantic (IBTS). Some Nordic data also exist from analyses of ROV/video observations and retrieval of lost fishing gear.

Especially the registration of marine litter items from bottom trawl surveys for fish stock assessments (IBTS/BITS) seems to have potential as a methodology for providing more systematic and consistent monitoring of amounts, composition and trends of litter on the sea floor since an internationally coordinated monitoring of fish populations is carried out twice per year in the North Sea and Baltic Sea. Among other sampling gears, these surveys utilize bottom trawls that are designed for monitoring of young fish and are therefore relatively fine meshed (16 $\mathrm{mm}$ mesh). While these trawls are able to effectively catch mainly larger specimens of litter, smaller fragments are likely to pass through the trawl and there are no systematic surveys in place to monitor small litter fragments and micro-litter. Non-fish/shellfish catches in Danish and Swedish surveys have been registered since 2010 using a range of broad categories: plastic, metal, glass, stone and wood, and other anthropogenic litter (DTU Aqua, personal com., NST, 2012, SwAM 2012). Litter data from IBTS and BITS surveys have been provided for both the Baltic Sea and the North Sea. Collection of data from scientific research vessels has intensified in recent years throughout Europe. More recently, the IBTS survey has adopted a new set of litter monitoring categories which initially have been developed by OSPAR and the MSFD Technical Subgroup for marine litter. These categories will also be applied in future in the Baltic BITS surveys. Although there are differences between the BITS and IBTS surveys in relation to sampling, these surveys together cover large areas in the Nordic region and may provide one of the few platforms for consistent sampling of litter on the sea floor. Alternatively, ROV transects can also be used in some areas. "Fishing for litter" and retrieval of lost fishing gear probably have more potential for use in connection with response indicators for actions, i.e. activities dealing with removal of litter from the sea.

Several Nordic countries have also been involved in "fishing for litter activities" coordinated by the Local Authorities International Environmental Organisation or Kommunernes Internasjonale Miljøorganisasjon (KIMO), which was founded by local coastal municipalities with a shared 
concern for the state of the environment. KIMO coordinates a number of "Fishing for Litter" projects that aim to reduce marine litter by involving the fishing industry. KIMO directly provides fishing boats with large bags to deposit the litter caught by fishers. Once the bags are full they can be deposited in participating ports, where litter is collected for disposal. KIMO Fishing for Litter projects operate in Scotland, SW England, Netherlands, Belgium, Isle of Man and the Faroes, with more than 40 ports and 400 boats (mostly bottom trawlers) involved. By 2013 the combined projects had removed more than 3,500 tonnes of litter from the sea during the years. From 2012 this also includes activities on "fishing for litter" in the Baltic Sea together with fishermen from three harbours on Swedish coastline (KIMO 2013). In Norway, plans for initiation of "fishing for litter" activities in cooperation with fishermen and harbours have also been considered (Fiskebåt 2012).

In Norway, other types of data for marine litter on the sea floor have been generated during many years by the registration of retrieval of derelict fishing gears (or gear components) that have been intentionally (dumping) or unintentionally (storms, collisions between gears, etc.) lost at sea. The Norwegian Directorate of Fisheries (Fiskeridirektoratet) has since 1983 registered annual amounts of retrieved fishing gear during clean-up operations at coastal fishing grounds. The registration includes retrieved gillnets, rope, fishing line, trawl wire, and other fishery related items (KLIF 2011, Norwegian Directorate of Fisheries 2013). Surveys are guided by information from fishers regarding the depths and locations where nets or other fishing gear were lost. The annual amount of gill nets retrieved in Norway during the period from 1983 to 2010 is shown in Figure 2.3.

Figure 2.3. Annual number of retrieval of lost gill nets in Norway in the period from 1983 to 2010

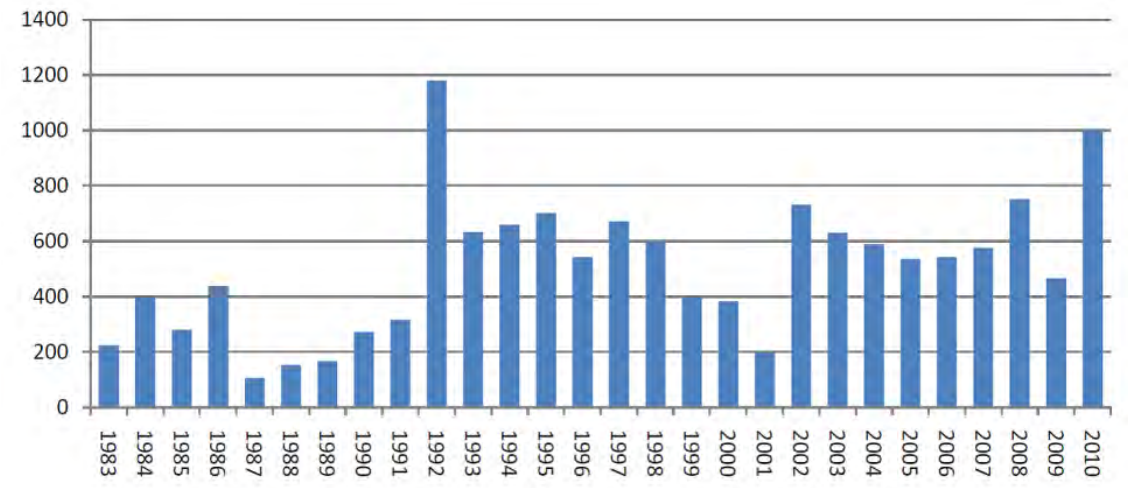

Figure copied from KLIF, 2011. 
Additionally there also exist video surveillance data of transects along five pipe-lines in the North Sea and the North Atlantic in the period from 1985 to 2009. These surveys showed that fishing nets, together with soft and hard garbage are the dominating litter types at all the five transects. However, it is also recognised that the smaller litter is not registered and the fishing gear is overrepresented as it can be caught within the pipe-line structures. Thus data from these surveys are not providing the complete description of the litter contamination of the region (KLIF 2011).

Another survey with several years of data for sea floor litter has been performed from the HAUSGARTEN observatory in the deep-sea, which is situated in Norwegian waters at the eastern Fram Strait west of Svalbard. HAUSGARTEN comprises of nine stations along a bathymetric gradient which is crossed by a latitudinal transect of currently eight stations at the depth of about 2,500 m. Image analyses revealed that the amount of litter items was within the range of 728-7,710 items $/ \mathrm{km} 2$ in the period of 2002-2011, where the majority of items (59\%) was identified as plastic materials (Bergmann \& Klages 2012).

In Denmark, some surveys with video sequences used for mapping benthic habitats in the North Sea, Kattegat, the Belt Sea, and the Baltic Sea have also been analysed for the presence of marine litter. The results showed that marine litter only rarely could be observed in the video sequences. Ghost nets and other types of lost fishing gear were, however, often observed entangled on ship wrecks. It was concluded that the surveys indicated that marine litter not could be regarded as a general problem for all benthic habitats, but rather a problem in certain accumulation areas (NST 2012).

An overview of some relevant surveys on marine litter on sea floor in the Nordic waters is given in Table 2.2. 


\begin{tabular}{|c|c|c|c|c|}
\hline Type, Method & Sea region & Country & Year(s) & Reference \\
\hline $\begin{array}{l}\text { Bottom-trawl } \\
\text { (BITS/IBTS) }\end{array}$ & BS, SK & K & 2010-2011 & NST (2012) \\
\hline $\begin{array}{l}\text { Bottom-trawl } \\
\text { (BITS/IBTS) }\end{array}$ & BS, SK & SE & 2010-2011 & SwAM (2012) \\
\hline $\begin{array}{l}\text { Retrieval of lost } \\
\text { fishing gear }\end{array}$ & NA & NO & $1983-2013$ & $\begin{array}{l}\text { KLIF (2011), Norwegian } \\
\text { Direct. of Fisheries (2013) }\end{array}$ \\
\hline "Fishing for Litter" & BS, NS & DK, FO, SE & 2002-2012 & KIMO (2004-2013) \\
\hline $\begin{array}{l}\text { ROV/video at } \\
\text { pipelines }\end{array}$ & NS & NO & 1985-2009 & KLIF (2011) \\
\hline $\begin{array}{l}\text { ROV/video, benthic } \\
\text { habitats }\end{array}$ & NS, SK & DK & 2011 & NST (2012) \\
\hline $\begin{array}{l}\text { ROV/video, deep } \\
\text { sea, Hausgarten }\end{array}$ & NA & NO & 2002-2011 & $\begin{array}{l}\text { Bergmann \& Klages } \\
\text { (2012) }\end{array}$ \\
\hline
\end{tabular}

Sea regions: Baltic Sea (BS), Skagerrak-Kattegat (SK), North Sea (NS), North Atlantic and Artic (NA). Countries: Denmark (DK), Norway (NO), Faroe Islands (FO), Finland (FI), Sweden (SE).

\subsection{Macro-litter floating in the water column}

To our knowledge no reported Nordic surveys exist on amounts and composition of floating macro-litter sampled directly from surface water layers or from deeper parts of the water column. According to Galgani et al. (2013), registration of floating macro-litter could be performed with either visual observation from e.g. vessel or aerial surveys or by automated camera surveys. Recently, OSPAR has suggested that plastic ingestion by seabirds, like fulmar, also could be used as indicator for floating litter, but in this report plastic ingestion by seabirds is described under uptake and impact of macro-litter in biota.

\subsection{Ingestion and impact of macro-litter in biota}

There exists some information on the ingestion and the impact of macrolitter in marine wildlife from the Nordic waters and especially for seabirds. In the Nordic countries, there seem only to be very scarce data on ingestion or impact of macro-litter on marine fish and invertebrates and to our current knowledge there has not been reported Nordic data for marine mammals. 


\subsubsection{Seabirds}

Like in other North Sea countries, most attention has been given to plastic ingestion by the sea-bird northern fulmar (Fulmarus glacialis) in the Nordic parts of the Skagerrak, the North Sea, the North Atlantic, and the Arctic waters, but not from the Kattegat where this species is less abundant or from the Baltic Sea, where it only occurs very rarely.

This is also one of the marine litter indicators recommended by OSPAR for the North Atlantic (OSPAR 2012). Northern fulmar has been identified as a good and sensitive indicator species for uptake of marine litter in biota, because this species like other procellariid seabirds forages exclusively at sea, frequently ingests floating litter from the sea surface, and has a high abundance and widespread distribution in the North Atlantic and Arctic (van Franeker et al. 2011).

Figure 2.4. Northern fulmar is a sensitive and suitable indicator for uptake of marine litter in biota, because of an increased risk for ingesting plastic litter at sea, probably due to their feeding strategy collecting items from surface waters

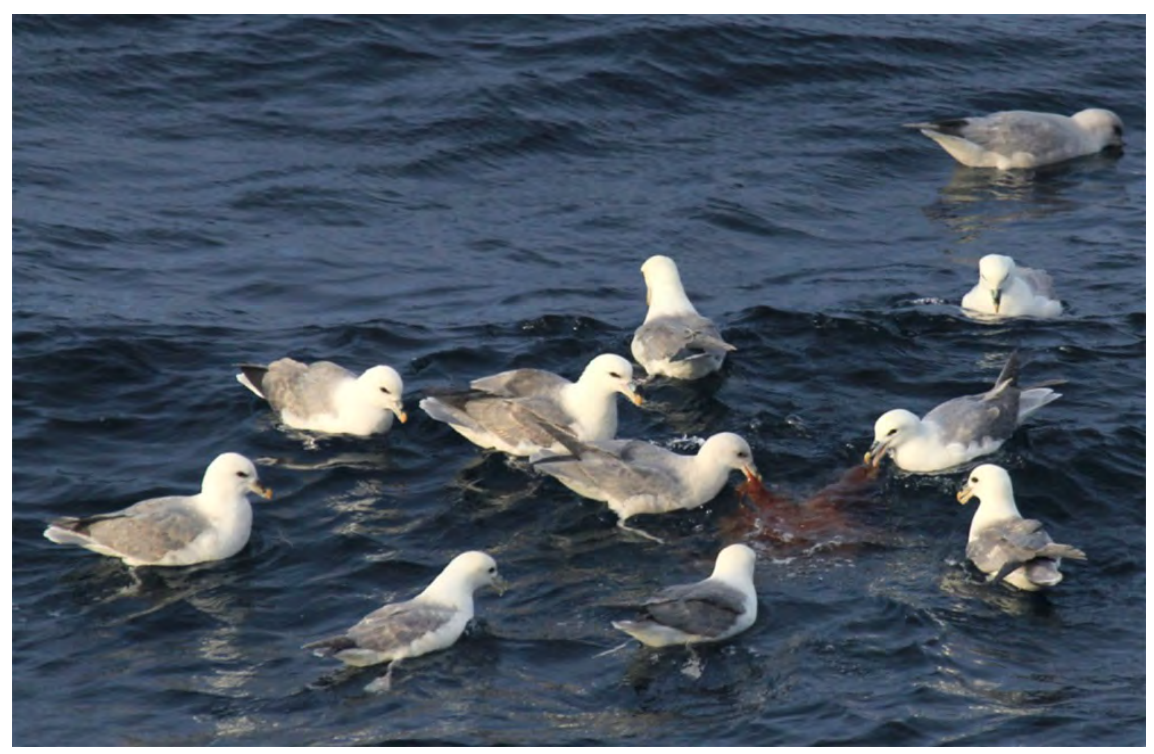

Photo: David Boertmann, North Atlantic 2011. 
During the early 1980s a long-term monitoring of plastic ingestion by northern fulmars was started in the Netherlands, and from the mid-1990s this was established as an annual program (van Franeker et al. 2011a). This resulted in the expansion of the Dutch research program to include all other North Sea countries including the Faroe Islands, Iceland, Sweden, Norway, and Denmark. The results from the North Sea and Skagerrak from 2002-2011, showed that the majority of the examined fulmars contained plastic litter in the stomachs (van Franeker et al. 2011a, OSPAR 2013). Of the, 1295 fulmars sampled in the period 2002-2007 95\% had plastic in the stomach (on average 35 pieces weighing $0.31 \mathrm{~g}$ ) with some regional variations (van Franeker et al. 2011a) and no significant decrease in plastic particles in fulmar stomachs has been detected over the last decade (OSPAR 2014).

Because of the high spatial coverage data from the North Sea and the potential level of biological impact, monitoring of plastics in fulmar stomachs has become one of the so-called "Ecological Quality Objectives" (EcoQOs) set by the OSPAR for the North-East Atlantic region (OSPAR, 2008, van Franeker et al. 2011a,b). According to van Franeker et al. (2011a), "the preliminary EcoQO defines acceptable ecological quality as the situation where no more than $10 \%$ of fulmars exceed a critical level of $0.1 \mathrm{~g}$ of plastic in the stomach". The EcoQO is now also proposed by WGGES as an indicator for Good Environmental Status (GES) relevant for the MSFD (Galgani et al. 2013). In these studies the plastics are divided into different categories, the two dominating ones being: industrial plastics (the raw granular feedstock for producers) and user plastics (from all sorts of consumer waste) (van Franeker 2013).

Regarding the results from the Nordic countries, 49-69\% birds from Skagerrak, and $44 \%$ of birds from Faroe Islands exceeded the EcoQOs limit of the $0.1 \mathrm{~g}$. In comparison, data from the later Icelandic study from 2011 showed that $28 \%$ of examined birds from North Atlantic waters exceeded this level. The Icelandic results support the hypothesis put forward by van Franeker in 1985 that the amount of plastic in fulmar stomachs decreased with higher latitudes in the Atlantic (Kühn \& van Franeker, 2012). This was also indicated in study on inter colony comparisons in the Canadian part of Arctic (Provencher et al. 2009). 
The OSPAR data on plastic contents in fulmar stomachs in different parts of the North-East Atlantic from the period 2002-2011 has almost all been provided by IMARES from the Netherlands. The OSPAR data have for now been made available only as summary data for different regional seas in the OSPAR region that include Nordic data as part of data for Skagerrak and Faroe Islands (van Franker et al 2011, OSPAR 2013). Data for one survey in Iceland in 2011 has also been published (Kühn \& van Franeker 2012). However, after 2011 a continuation of the fulmar activities will have to rely on national contributions that can imply national research, but could also be conducted centrally and at least requires associated centralized funding to support international coordination and integration (van Franeker pers. comm).

Among the Nordic countries, Norway is the only country that has initiated national surveys on fulmar stomachs as a marine litter indicator.

Fulmars found dead during winter time on the Norwegian North Sea coast in the Lista and Rogaland areas have over the period 2002/2003 to $2012 / 2013$ been examined for plastic ingestion. The running 5-year average levels for the last years in the period show that approximately $65 \%$ of the birds contained $>0.1$ g plastic, i.e. above OSPARs EcoQO (Figure 2.5). Preliminary results from the northern Norway, shows for comparison that about $34 \%$ of the fulmars caught accidentally during fishery for Greenlandic halibut contained $>0.1 \mathrm{~g}$ plastic (Anker-Nilssen 2014).

Preliminary results from another Norwegian study in 2013-2014 on fulmars from Svalbard in the high Arctic show that up to $88 \%$ of the 40 examined fulmars had ingested plastic, averaging at $0.08 \mathrm{~g}$ or 15.3 pieces per individual, where $22.5 \%$ exceeded OSPARs EcoQO (Trevail et al. 2014). An older unpublished study on fulmars from Svalbard in 1984 had for comparison previously found that approximately $30 \%$ of the examined fulmars had ingested plastic (Gabrielsen 2013). Thus the elevated levels of plastic ingestion in fulmars from Svalbard highlight the need for mitigation of plastic pollution, and also in the Arctic (Trevail et al. 2014). 
Figure 2.5. Proportion of northern fulmars with more than $0.1 \mathrm{~g}$ plastic in the stomach that have been collected during winter time at North Sea coasts in Norway

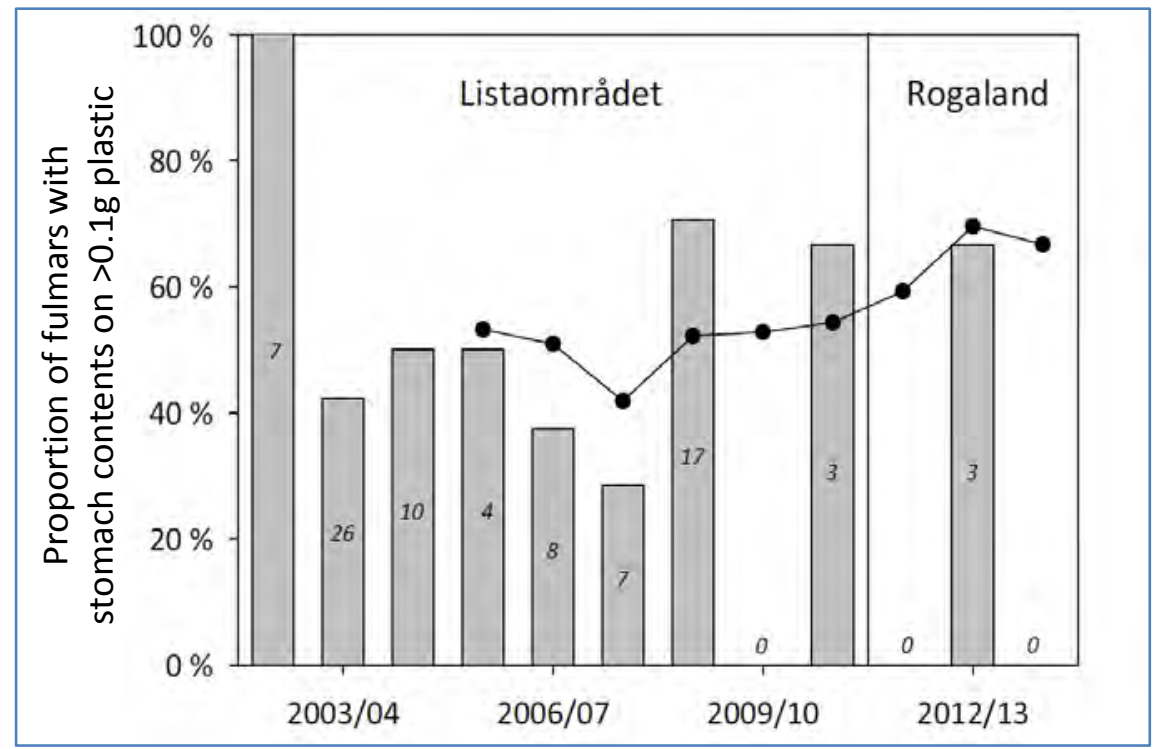

Anker-Nilssen, 2014.

Only a limited amount of studies have reported higher incidences of plastic ingestion in other species than the procellarid seabirds like fulmars - and also albatrosses, shearwaters etc. from other sea regions. However, one study with necropsy examinations on the auk thick-billed murre (Uria lomvia) from Southwest Greenland in 1988-1989 found that $6 \%$ of 202 birds contained plastic in their stomachs (Falk \& Durinck 1993, Provencher et al. 2014) indicating that auks also may also be a potential indicator for plastic ingestion in seabirds.

Only scarce data can be found regarding the issue of entanglement of seabirds in marine litter such as derelict gill nets, ropes, and trawl wires in the Nordic countries. Among seabirds, especially the Northern gannet (Morus bassanus) seems to be susceptible to marine litter, although no consistent registration has been performed of this in the Nordic waters. Gannet remains the species most frequently found entangled among all beached birds in the Dutch and German part of the southern North Sea. $5-20 \%$ of the gannets, often found when dead, have been reported as entangled since surveys started in the 1980s and until today (Fleet et al. 2009). Some observations of gannet entangled in pieces of rope have also been made at e.g. the Danish North Sea and Skagerrak coasts, where gannets can forage in large numbers (Strand, unpubl.). As well as being mistaken for food, plastics are also used as nesting material by some seabirds. For instance, over $90 \%$ of the 30,000 gannet nests on Grass- 
holm Island (in UK) contained plastic (OSPAR 2009). This indicates the extent of plastic pollution in surrounding waters, as gannets collect almost all of their nest material at sea.

Figure 2.6. Seabirds like northern gannet often collect and carry plastic litter to be used as nest material in colonies in the North Sea and the North Atlantic

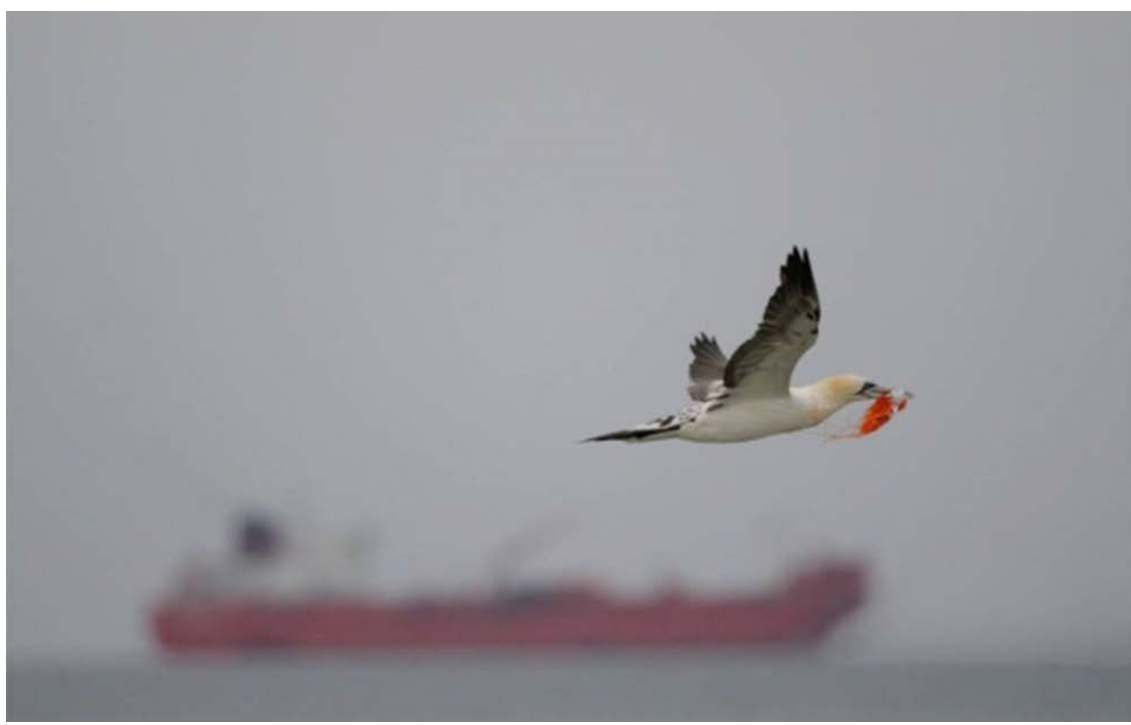

Photo: Søren Kristensen, Denmark 2012.

Other seabirds are also collecting marine litter as nest material. For instance, studies of the nesting material used by the sea-bird kittiwake (Rissa tridactyla) have been carried out by quantifying the percentage of nests containing plastic litter. A study on a kittiwake colony in NorthWest-Denmark visited in both 1992 and 2005 found that 39\% of the 466 nests analysed in 1992 contained plastic, whereas $57 \%$ out of 311 nests contained plastic in 2005 (Hartwig et al. 2005).

\subsubsection{Marine fish and invertebrates}

From the Nordic countries there is very little data on ingestion of or impact of macro-litter on marine fish and invertebrates. However, there is information on the entanglement of fish caught by derelict fishing gear retrieved during clean-up operations at the coastal fishing grounds in Norway. For instance in 2011, 14,000 kg fish and 12,000 crabs were registered from 1,100 derelict gill-nets and 54 crab-traps (Norwegian Directorate of Fisheries 2011). Other observations have also been reported, e.g. mackerel entangled in elastic band (Norden Andersen 1978). 
From our neighbouring countries some information is available on that plastic fragments have also been observed in the digestive tract of fish. For instance ingestion of pieces of plastic have been observed in a number of twaite shad (Alosa fallax) collected in some Baltic Sea estuaries like Gulf of Gdansk (Skóra et al. 2012). Similar observations have also been made for cod (Gadus morhua) from the German part of the North Sea and the Baltic Sea during examination of stomach contents for food items (Fricke N., pers. comm.).

An overview of some relevant studies on marine litter in relation to biota from the Nordic waters is given in Table 2.3.

\begin{tabular}{|c|c|c|c|c|}
\hline Type, Method & Sea region & Country & Year(s) & Reference \\
\hline Litter in Fulmar & NS, SK, NA & $\begin{array}{l}\mathrm{DK} / \mathrm{NO} / \mathrm{SE}, \\
\text { FO }\end{array}$ & 2002-2011 & $\begin{array}{l}\text { Van Franeker, 2011; OSPAR } \\
2014\end{array}$ \\
\hline Litter in Fulmar & NS, NA & NO & 2003-2013 & Anker-Nilssen, 2014 \\
\hline Litter in Fulmar & NA & NO & 2013-2014 & Trevail, pers. comm. \\
\hline Litter in Fulmar & NA & IS & 2011 & Kühn \& van Franeker, 2012 \\
\hline $\begin{array}{l}\text { Litter in } \\
\text { Thick-billed murre }\end{array}$ & NA & $\mathrm{GL}$ & 1988-1989 & Falk \& Durinck, 1993 \\
\hline $\begin{array}{l}\text { Entanglement of } \\
\text { Northern gannet }\end{array}$ & & \multicolumn{3}{|c|}{ No systematic registration, only observations } \\
\hline $\begin{array}{l}\text { Litter in nests of } \\
\text { Kittiwake }\end{array}$ & NS & DK & 1992-2005 & Hartwig et al. 2007 \\
\hline $\begin{array}{l}\text { Entanglement of fish } \\
\text { and craps in ghost nets }\end{array}$ & NA & NO & $19 x x-2011$ & $\begin{array}{l}\text { Norwegian Directorate of } \\
\text { Fisheries, } 2011\end{array}$ \\
\hline
\end{tabular}

Sea regions: Baltic Sea (BS), Skagerrak-Kattegat (SK), North Sea (NS), North Atlantic and Artic (NA). Countries: Denmark (DK), Norway (NO), Faroe Islands (FO), Iceland (Is), Finland (FI), Greenland (Gr), Sweden (SE). 


\section{Overview of studies on micro-litter indicators with emphasis on findings in the Nordic countries}

Marine micro-litter has received much public and scientific attention over the past decade, and the possible consequences it may have on marine ecosystems have been thoroughly described in reports and scientific articles. Still, the number of field studies on the actual amounts, composition and impact of micro-litter in the marine environment are surprisingly few in relation to the attention the problem has been given. In an extensive review on marine microplastic (an important fraction of micro-litter) in general and in Dutch coastal waters in particular, this was also one of the conclusions for the North Sea region (Leslie et al. 2011).

"Micro-litter" comprises a diverse group of particulate materials originating from human activities that besides different kinds of plastic, also includes e.g. non-synthetic textile fibres and road dust. It could hence be expected that the fate of particles made up of these various materials is equally diverse as factors like density, size and shape affect distribution and residence times of microscopic particles in different parts of the marine environment.

Micro-litter particles occur, just like macro-litter, in almost all parts of the marine environment, but the relative distribution of particles between the different ecosystem compartments (e.g. surface and deeper water layers, tidal and subtidal sediments, different organisms etc.) is still unknown.

Micro-litter occurs as:

- Floating in surface waters and in deeper parts of the water column.

- Deposited in subtidal, tidal sediments and on shorelines.

- Taken up by marine organisms. 
Microplastic can be divided into two overall groups, primary (engineered particles) or secondary microplastic (fragments of macroplastic litter). Of these, secondary plastic is expected to be the most common microplastic in the sea (Leslie et al. 2011). This is because secondary microplastic can originate from fragmentation/degradation of macro-litter from various sea- and land-based sources, whereas the sources to primary microplastic are more restricted to their uses in e.g. personal care products (mainly from households), industrial scrubs and sandblasting products, and industrial production where plastic (resin) pellets are used as raw material for production of various macroplastic items.

There is still limited knowledge of the contribution of different sources of microplastic particles in the sea, and also in the Nordic countries. Recently, studies in Finland and Sweden on effluents from waste water treatment plants (WWTPs) have indicated that they can be a significant source of microlitter in the aquatic environments. For instance, concentrations of microplastic of 7,000-30,000 particles $(>300 \mu \mathrm{m})$ and $60,000-$ 80,000 particles $(>20 \mu \mathrm{m})$ per cubic meter were found in inlet water from three different WWTPs in Sweden (Magnusson \& Wahlberg 2014). Although the main part $(70-100 \%)$ of the microplastic particles was maintained inside the WWTPs, outlet water, i.e. the effluent going into the receiving aquatic environments, still contained considerable amounts of microplastic with 1-100 particles $(>300 \mu \mathrm{m})$ and 1000-10000 particles $(>20 \mu \mathrm{m})$ per cubic meter (Magnusson \& Wahlberg 2014).

The most basic identification of marine micro-litter in the laboratory is done with stereo microscopy, where micro-litter particles at first can be grouped into four categories according to their shapes, i.e. as granules, flakes, spherules and fibres (Figure 3.1). Stereo microscopy may not always be enough to distinguish between plastic and other anthropogenic materials, e.g. non-synthetic textile fibres, and in these cases the plastic particles potential to melt when heated may be used for identification (Magnusson \& Wahlberg 2014). To distinguish between different kinds of the plastic material and identify specific types of polymer, analysis with Fourier Transform infrared (FT-IR) or RAMAN spectroscopy is required. These methods are however rather expensive and time consuming and can in practice only be performed on a limited number of particles in a study. 
Figure 3.1. Examples of different types of microplastic particle, i.e. granules, flakes, spherules and fibres, found in sediments from Danish waters

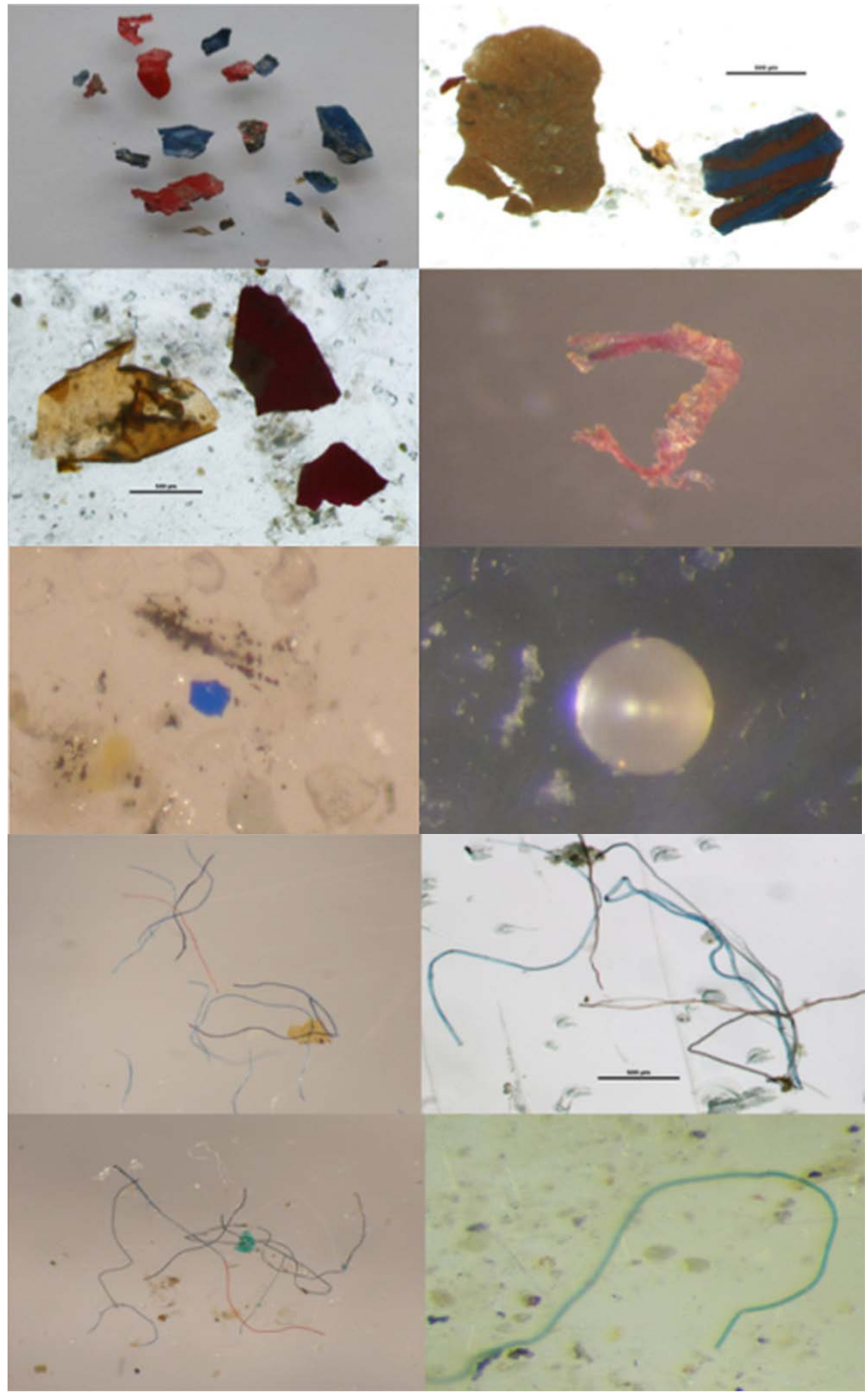

Photo: Jakob Strand. 
There is no general consensus about a specific size nomenclature although it has been suggested that microplastics should be defined as particles $<5$ $\mathrm{mm}$ (Hidalgo-Ruz et al. 2012). This is also the upper size limit recommended by the working group dealing with good environmental status under the MSFD (WG-GES) (Galagani et al. 2013). The lower size limit is highly dependent on the sampling methods and therefore varies considerably between published studies. As a consequence of this, WG-GES assess that the tools for creating a harmonized protocol for quantifying microplastic particles in all environmental matrices still has a low level of maturity and need to be further developed (Galgani et al. 2013). However, there is a definite need for a size definition when monitoring microplastics so that results over periods of time and from different geographical areas may be compared.

\subsection{Microplastic in the water column}

Studies in the western North Atlantic Ocean and the Caribbean Sea showed that the concentration of microplastic particles $>0.3 \mu \mathrm{m}$ in surface water had not increased between the years 1986 and 2008, in spite of a significant increase in global plastic use over the same period of time (Law et al. 2010). This implies that many plastic particles spend a limited time in the water column. In shallow areas close to the coast, the amount of micro-litter in the water column seem to depend strongly on weather conditions and concentrations increase after storm events (Lattin et al. 2004). Considering this risk for large temporal variations in field data, microplastic concentrations in the water column must be interpreted with caution. Also, the efficiencies of the sampling methods presently used are still not well investigated and comparisons between different methods are few, which further complicates the interpretation.

Most sampling of micro-litter in the water column has been done by trawling with plankton net or by pumping water through a filter. Filtering the research vessel's continuous water intake for microplastic particles is another potentially method currently studied by DTU Aqua in Denmark in connection to an eel survey extending from the Danish coast to the Sargasso Sea and back (Sørensen, pers.com.). The Technical Subgroup on Marine Litter (TSG ML) has indicated that they may recommend that monitoring of marine micro-litter should be done on surface water and carried out with a Manta trawl with a $333 \mu \mathrm{m}$ mesh. The Manta trawl is specifically designed to sample in the upper $0.5 \mathrm{~m}$ of the water column (EU 2013).

In a study of stations along the Swedish coast line, from the west coast close to the Norwegian border to the southern Bothnian Sea, the 
number of plastic fragments in the water surface, sampled by pumping water through a $300 \mu \mathrm{m}$ filter, amounted to $\sim 1$ particle $\mathrm{m}^{-3}$, and the number of non-synthetic fibres (e.g. cotton) was slightly higher than synthetic fragments (Magnusson \& Norén, 2011). In a study from the Gulf of Finland particles $>333 \mu \mathrm{m}$ were collected with Manta-trawl and the number of plastic particles was found to vary between 0 and 0.7 particles $\mathrm{m}^{-3}$ at the different sampling stations (Magnusson 2014).

Figure 3.1. Microplastic concentrations $>330 \mu \mathrm{m}$ in surface water sampled with manta-trawl in Rauma and Turku in Finland in 2013

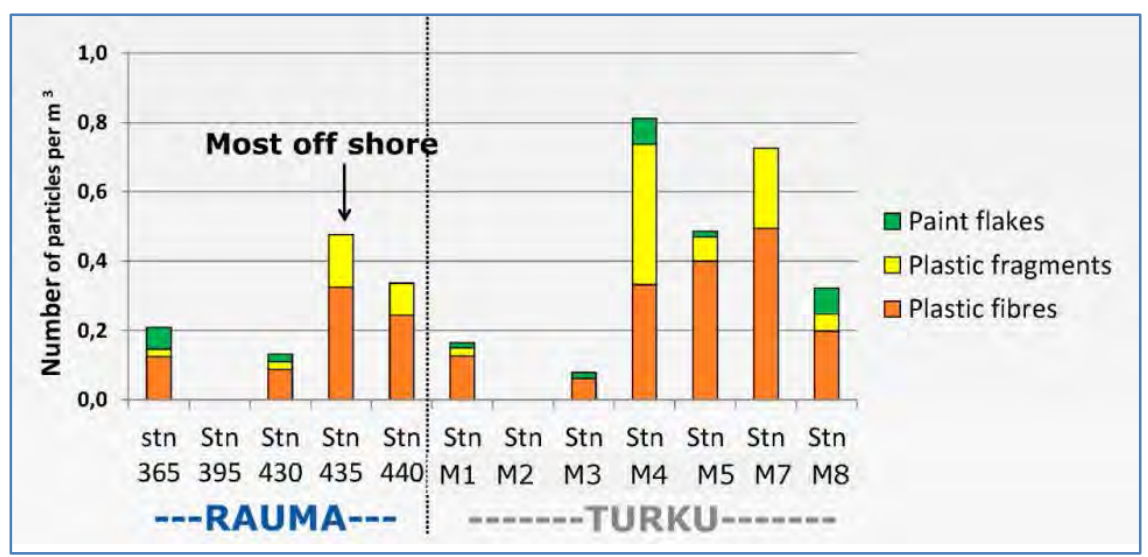

Magnusson, 2014b.

Studies on microplastics in sea water have also been performed for instance in the British part of the North Sea and North Atlantic using Continuous Plankton Recorder (CPR) and Manta trawl (Galgani et al. 2011). When analysing samples from the CPR from the 1990s the microplastics concentration in the British part of the North Sea and North Atlantic were found to be on average 0.03 items $\mathrm{m}^{-3}$ (Thompson et al. 2004). It is however difficult to compare these figures with results from studies by Magnusson and Norén (2011) and Magnusson (2014), since different sampling methods were used.

Several field studies of surface water around the Swedish coast line and in the Gulf of Finland have revealed that the microplastic fraction of micro-litter is dominated by plastic fibres and that the number of plastic particles of any other shape is fairly low (Norén 2010, Magnusson \& Norén 2011, Magnusson 2014b). The diameter of most fibres were $<<300 \mu \mathrm{m}$, which means that whether or not they were collected depended on what direction the fibers had when hitting the trawl net or filter where mesh sizes were 330 and $300 \mu \mathrm{m}$, respectively. It is hence important to keep in mind that all data coming from sampling based on 
filtering water actually shows the number of micro-litter particles retained on filters with $300 \mu \mathrm{m}$ mesh size (or whatever mesh size that has been applied), rather than "micro-litter particles $>300 \mu \mathrm{m}$ ". Also, it cannot be excluded that when there are large amounts of biological material in the water, anthropogenic fibres get entangled and a larger fraction is retained in the trawl or on the filter, whereas in samples with less biological material more anthropogenic fibres pass through the mesh of the sampling device.

The large dominance of plastic fibres in Nordic surface waters is in contrast to findings in e.g. the North American Great Lakes, where plastic microspheres were much more common (Eriksen et al. 2013).

\subsection{Microplastics on the beaches and in sub-tidal sediments}

Most methods used to extract microplastics from sediments are based on elutriation with high saline solutions and some methods also include a digestion step to eliminate biological material (Johansson 2011, Claessens et al. 2013, Strand et al. in prep.).

In an Icelandic study of twelve sandy beaches, situated along a gradient from the urban area around Reykjavik to more remote parts further north, the occurrence of microplastic particles $(1-5 \mathrm{~mm})$ was found to be more frequent at beaches in the urban area than in semi-rural ones (Dippo 2012). At the rural beaches no microplastics was found. However, within the semi-rural areas the distribution between different beaches was very patchy, indicating that the effect of ocean currents is important. The same conclusion was drawn from a study from a remote area on the North American west coast, Puget Sound, where the sediment was analysed for microplastics at twelve locations in each of three bays and it was found that at one of these locations the microplastics concentration was higher than the sum of the other eleven locations (Gilman 2013). A study on distribution of microplastics on different parts of a beach at the Danish North Sea coast showed that microplastic particles were abundant. Microplastics occurred with densities ranging from 112-2,480 particles $\mathrm{kg}^{-1}$ dry weight (DW) and with synthetic fibres as the dominant fraction. The high variance between subsamples was due to highly irregular distribution on the beaches. A vertical transect from coast to upper zones of the beach showed the highest levels generally occur in the upper zones (Derksen et al. 2012). 
Microplastic also occurs deposited on the sea floor in sub-tidal sediments. A Danish study on distribution of microplastic particles (38 $\mu \mathrm{m}-1$ $\mathrm{mm}$ ) in sediments in a transect from the Baltic Sea towards the North Sea found 60-3,600 particles $\mathrm{kg}^{-1}$ sediment DW and again with fibres as the dominant fraction (Strand et al. in prep.). These levels were comparable with findings in some of our neighbouring countries. For instance a Belgian study observed microplastic $(38 \mu \mathrm{m}-1 \mathrm{~mm})$ in concentrations between 50-400 microplastic particles $\mathrm{kg}^{-1}$ sediment DW in all sediments sampled in gradients extending from large harbours and also at a some more randomly selected beaches in the North Sea (Claessens et al. 2011). The results from the Danish study also indicated that normalisation of microplastic densities to adequate sediment characters can reduce the variability caused by natural heterogeneity between samples and thereby increase the power of identifying more or less affected areas. Strong relationships between the content of microplastic and both content of total organic carbon (\%TOC) and fine sediment fraction $(<63 \mu \mathrm{m})$ in sediments were found throughout the area, supporting the theory that microplastic will accumulate in sedimentary depositional areas - i.e. with parallels to organic pollutants adsorbed to organic materials. Positive correlations were also established to PAHs, alkylphenols and phthalates in sediments, probably due to co-variation with sources and TOC (Strand et al. in prep.). The fact that fibres are the dominating type of microplastic is similar to the findings in the surface water along the Swedish coast and in the Gulf of Finland (Magnusson and Norén 2011, Magnusson 2014b.).

A few Nordic studies have also put attention to pollution with paint flakes from constructions or from ship hulls in harbours and their potential release of toxic chemicals like TBT and PCBs (Jartun et al. 2009, Eklund et al, 2008). Strand et al. (in prep) also reported findings of microplastic flakes identified as acrylic paint in sediments from coastal areas in Denmark, especially in areas with high densities of ships. Findings from Antarctica indicate also that paint flakes with toxic chemicals from ship hulls can be an important issue in areas often covered by sea ice, and especially in shipping lanes, where ice-breaking vessels cut channels through sea ice (Negri \& Marshall 2009). Such ice-breaking activity also takes place in the Arctic and other parts of the Nordic waters through wintertime. 


\subsection{Microplastics in marine biota}

Microplastic particles can be taken up by organisms at various levels within the food web. Due to their small size, microplastic particles may be ingested by low trophic fauna (Wright et al. 2013). Consumption of the prey containing microplastic particles can be an indirect way for microplastic ingestion by fish. Zooplankton, a prey item of many fish species and especially those mid-trophic level fish, upon which other larger fish feed, have been shown to ingest microplastics (Cole et al. 2013). In an experimental study it was shown that $10 \mu \mathrm{m}$ styrene microparticles were ingested by several Baltic Sea zooplankton taxa (mysid shrimps, copepods, cladocerans, rotifers, polychaete larvae and ciliates) and that the particles were also transferred between trophic levels from meso- to macrozooplankton (Setälä et al. 2014). To our knowledge there is however no reports on microplastic in field sampled zooplankton from Nordic waters. Other experimental studies have also shown trophic transfer of microplastics e.g. from mussels to crabs (Farrell \& Nelson 2013).

In a study by Von Moos et al. (2012) polarized light microscopy was used to investigate whether or not blue mussels (Mytilus edulis) ingested fragments of microplastic ranging from $>0-80 \mu \mathrm{m}$ and whether these fragments were taken up into the mussels cells and tissue. It was found that microplastic particles did get drawn into the mussels gills and transported onwards to the stomach digestive gland, where they accumulated in the lysosomal system, i.e. providing evidence that microplastic particles are taken up into cells. Observed histological changes and a strong inflammatory response also confirmed that the particles caused significant effects on the tissue and cellular level.

Some North Sea studies on field sampled benthic invertebrates like mussels, polychaetes and crustaceans including shellfish for human consumption have also demonstrated uptake of microplastic (Van Cauwenberghe et al. 2012, Cauwenberghe \& Jansen 2014).

The study of the gut contents of Norway lobster (Nephrops norwegicus) collected in the Clyde Sea in Scotland revealed plastics in the stomachs of $83 \%$ of the sampled animals (Murray \& Cowie 2011). In 62\% of them, filaments of fibres within the range of $\mathrm{mm}-\mathrm{cm}$ (in length), were found as tightly wound balls of plastic strands. Raman spectroscopy indicated that some of these strands probably came from "chafer mats", which are multistrand polypropylene rope fittings applied to fishing gears to protect gears from abrasion. In addition to examining the ingested plastics of wild Nephrops, Murray and Cowie (2011) also conducted experimental studies where they fed pieces of fish containing strands of plastic rope to caged 
animals. The plastic strands were found to be ingested by the Nephrops but not excreted.

In a study of fish from the North Sea 1,200 individuals of seven common species were examined and microplastic particles $(0.04-4.8 \mathrm{~mm})$ were found in $3 \%$ of the individuals and in five of the seven species (Foekema et al. 2013). However, 80\% of the individuals with plastics contained only one plastic item, suggesting that the particles did not accumulate in the fish gut for very long time. Another study from the English Channel observed microplastic particles in 10 species of fish from the English Channel. Of 504 examined fish the authors found plastics in the gastrointestinal tracts of $37 \%$. All of the ten studied species had ingested plastics, including both pelagic and demersal fish species. Polyamide (36\%) and rayon (58\%) were the types of plastic most commonly encountered (Foekema et al. 2013).

In the Nordic countries only few studies on occurrence of microplastic in marine organisms have been carried out. For instance, fibre particles of anthropogenic origin have been found in the faeces of sediment living brittle stars and polychaetes from Gullmarsfjorden at the west coast of Sweden. The field sampled specimens were kept in clean water to allow them to purge their guts, and plastic fibres were detected in the faecal material (Johansson 2011). Another study on blue mussels sampled at

two location in the vicinity of Copenhagen in Denmark found on average 1.2-2.5 particles per mussel corresponding to 0.6-1.5 microplastic particles per gram wet weight (Agersnap 2013). The same study also found microplastic in the gut of three fish species, i.e. eelpout (Zoarces viviparus), cod (Gadus morhua) and sculpin (Myoxocephalus scorpius) with on average 0.3-2.3 microplastic particles per fish.

Another fish study on 45 Herring (Clupea harengus) and 46 whiting (Merlangius merlangus) from the Belt Sea in Denmark showed that 27$31 \%$ of the fish contained 1-4 microplastic particles in their gut (Sørensen et al. 2013).

In all of the field studies, synthetic fibres have been assessed to be the dominating fraction of microplastic taken up by the organisms, which is in line with the findings of micro-litter in water column and sediments.

An overview of some relevant studies on micro-litter in water column, sediments and biota from the Nordic waters is given in Table 2.4. 
Table 2.4. List of some Nordic studies on micro-litter in water column, sediments and biota

\begin{tabular}{|c|c|c|c|c|}
\hline Type, Method & Sea region & Country & Year(s) & Reference \\
\hline Water column & SK, BS & SE & 2007,2010 & $\begin{array}{l}\text { Norén, 2007; } \\
\text { Norén \& Magnusson, } 2011\end{array}$ \\
\hline Water column & SK & NO & 2010 & Norén \& Naustvoll 2011 \\
\hline Water column & BS & $\mathrm{FI}$ & 2012 & Setälä, unpubl. \\
\hline Water column & BS & $\mathrm{FI}$ & 2013 & Magnusson, 2014 \\
\hline Tidal sediment and beach sand & NS & DK & 2009-2010 & Derksen et al. 2012 \\
\hline Tidal sediment and beach sand & NA & IS & 2011 & Dippo, 2012 \\
\hline Sub-tidal sediment & BS, SK, NS & DK & $2012-2013$ & Strand et al. in prep. \\
\hline Sub-tidal sediment & SK & SE & 2010 & Johansson, 2011 \\
\hline Brittlestars, faeces & SK & SE & 2010 & Johansson, 2011 \\
\hline Mussels and fish & BS & DK & 2013 & Agersnap 2013 \\
\hline Fish & BS & DK & 2013 & Sørensen et al. 2013 \\
\hline
\end{tabular}

Sea regions: Baltic Sea (BS), Skagerrak-Kattegat (SK), North Sea (NS), North Atlantic and Artic (NA). Countries: Denmark (DK), Norway (NO), Iceland (Is), Finland (FI), Greenland (Gr), Sweden (SE). 


\section{Status for management actions on marine litter with relevance for Nordic waters}

\subsection{Current status for implementing Marine Strategy Framework Directive and national management plans in the Nordic countries}

The Marine Strategy Framework Directive (MSFD) is currently the most important European legislation concerning marine litter.

In addition to MSFD, three main goals for reducing the occurrence and impact of marine litter have been adopted by the EU as part of the Honolulu Strategy. The Honolulu Strategy is a framework established by the United Nations Environment Programme (UNEP) and National Oceanic and Atmospheric Administration (NOAA) for comprehensive and global effort to reduce the ecological, human health, and economic impacts of marine debris (UNEP \& NOAA 2012). The three goals are:

- Goal A: Reduced amount and impact of land-based sources of marine debris introduced into the sea.

- Goal B: Reduced amount and impact of sea-based sources of marine debris including solid waste, lost cargo, abandoned, lost or otherwise discarded fishing gear (ALDFG), and abandoned vessels introduced into the sea.

- Goal C: Reduced amount and impact of accumulated marine debris on shorelines, in benthic habitats, and in pelagic waters.

The Nordic countries consist of Denmark (including Greenland and the Faroe Islands), Norway, Sweden, Finland, and Iceland. Denmark, Sweden, and Finland are members of EU whereas Norway and Iceland are not. Greenland and Faroe Islands are not members of EU, although they are part of the kingdom of Denmark. Norway and Iceland have developed national management plans for marine litter that are almost comparable with the guidelines for the implementation of MSFD. 
Implementation of MSFD must follow the time schedule below (Anon. 2008):

- 2012: Initial assessment of the current environmental status completed.

- 2014: Monitoring programme established and implemented.

- 2015: Programme of measures to achieve or maintain GES developed.

- 2016: Programme of measures to achieve or maintain GES implemented.

- 2020: GES achieved.

GES shall be determined on the basis of qualitative descriptors of which marine litter is one of eleven. GES for marine litter is defined as "Properties and quantities of marine litter do not cause harm to the coastal and marine environment" (Anon. 2008). Marine litter is highlighted in the MSFD as a significant pressure for which a monitoring programme has to be established and measures have to be implemented. An outline for this work is given in the Commission Decision on criteria and methodological standards (Anon. 2010) that emphasises four indicators for marine litter (see Table 1.1).

The current status of strategies and actions for marine litter in the Nordic countries in relation to the MSFD and internationally is reviewed below. The indicators selected in national monitoring plans for the coming years is summarised in Table 4.1.

\section{Denmark}

In the Danish marine strategy (NST, 2012a,b) the environmental objectives for marine litter are 1) litter and its degradation products do not cause harm to marine ecosystems and species and do not support spreading of non-indigenous and invasive species, and 2) litter and its degradation products do not have a significant negative socio-economic impact on marine professions and professions associated with marine areas including tourism. Due to lack of knowledge, an operational objective has not yet been decided for microparticles. Further, it is mentioned in the strategy that in order to come up with quantitative targets it is necessary to A) map macrolitter at the sea floor and on shores, and B) gather scientific data to establish reference levels for marine litter and specify actions to achieve significant reductions in the amount of litter by 2025 compared to 2015. The indicators for the targets will, according to the Danish plans for MSFD monitoring (NST, 2014), be based on I) amount and composition of litter at reference 
beaches, II) monitoring of litter as by-catch during fishery surveys (BITS/IBTS), and III) microplastic in fish and sediment.

\section{Sweden}

In the Swedish marine strategy (SwAM 2012) the environmental objectives for marine litter are 1) litter and its degradation products do not cause harm to the marine environment, and 2) the amount of litter that do have or may have a negative impact on marine organisms is reduced. The indicators for the first objective are A) amount of litter at reference beaches, and B) amount of litter at the sea-floor, whereas an indicator for the second objective has not been decided upon due to lack of knowledge. Microlitter will be assessed in the water column and point sources. The target for litter at reference beaches is a decrease in the amount of litter with the long-term goal that the marine environment is free of litter. The target for litter at the seafloor is a decrease in the amount of litter with the long-term goal that the marine environment is free of litter.

\section{Finland}

In the Finnish marine strategy (Setälä 0., pers. comm) the environmental objective is that the amount of litter and its degradation products in the sea or entering the sea are at levels causing neither chemical nor physical harm to the marine ecosystem or harm the economic use of the marine environment including the shore. The overall target is that the amount of litter is decreasing. The indicators for the objective are: 1) the amount and nature of visible litter on the shores, 2) the amount of collected litter, 3) the amount and nature of visible litter on the seafloor, and 4) the amount of microlitter in surface water at the open sea areas, with particles $>330 \mu \mathrm{m}$.

\section{Norway}

Not being a member of the European Union a Norwegian MSFD strategy has not been established. However, similar considerations have been made and formulated in status documents to be used for the marine management plan in Norway (KLIF 2011). It is stated that there is a need to map the distribution and composition of litter and to identify the yearly loading and the sources. To obtain this information and to follow the trends and impacts of litter it is recommended to monitor litter at beaches and at sea using the method described by OSPAR. Further it is suggested to monitor litter at the seafloor in collaboration with the oil industry. It is also mentioned that there is a general lack of knowledge about micro-litter. 


\section{Iceland}

Iceland is, like Norway, not an EU Member State. Marine litter is, however, an issue included in the national management plan. The Icelandic monitoring plan is at the moment aiming at monitoring amount and composition of litter at reference beaches.

Iceland has recently (September 2014) been a host for the International Conference on Plastic in the Marine Environment, organized by the Icelandic chairmanship of The Nordic Council of Ministers that aimed to give an overview of the current knowledge on the issue of plastic marine pollution, and to identify reasonable and effective measures to minimize plastic waste in the marine environment. In addition, a unique project has been in function since 2005, based on an agreement between Icelandic Recycling Fund (Úrvinnslusjóður) and Federation of Icelandic Fishing Vessel Owner, which aims to recycle material from waste fishing nets.

\section{Faroe Islands and Greenland}

Marine litter is not at the moment targeted as a specific element within their national marine management plans.

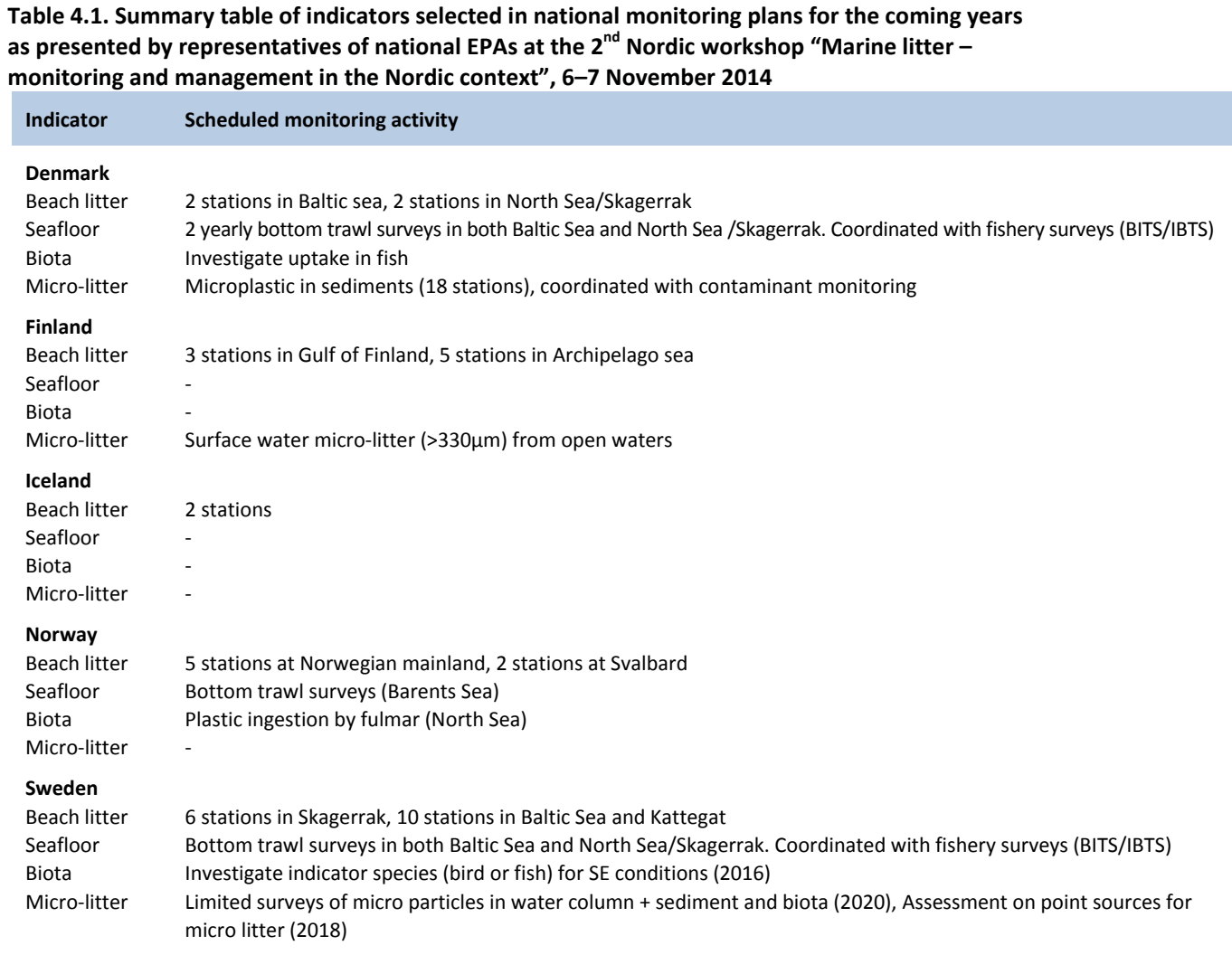




\subsection{Status for some international activities related to management of marine litter}

The environmental and legislative status for marine litter in Europe is given by the London Convention 1972, Washington declaration 1995, MARPOL convention (Annex V) 1998, OSPAR convention 1998, Marine Strategy Framework Directive 2008 and HELCOM Ministerial Declaration 2010 as described in e.g. Trouwborst (2011). Below is listed the most important international organizations addressing marine litter.

\section{UNEP}

The United Nations Environment Programme (UNEP) is the environmental programme of the United Nations (UN). Marine litter became a priority issue of UNEP in 2004 and it was decided that UNEP should take lead in developing global and regional activities (UNEP 2009). Subsequently, UNEP's Regional Seas Programme (RSP) has implemented activities concerning marine litter in co-operation with regional organizations (e.g. see OSPAR below). In many regions these activities have been consolidated by a legal framework, a so-called Regional Sea Convention (RSC), such as the HELCOM and OSPAR Conventions.

In 2012, UNEP has also together with the National Oceanic and Atmospheric Administration (NOAA) in the USA been lead in formulation of the Honolulu Strategy, which is a framework established for a comprehensive and global effort to reduce the ecological, human health, and economic impacts of marine debris (UNEP \& NOAA 2012).

In 2013, a key working group (WG-40) under the Joint Group of Experts on the Scientific Aspects of Marine Environmental Protection (GESAMP) was formed as an advisory body for the UN system on the scientific aspects of marine environmental protection with the International Maritime Organization (IMO) as an administrative secretariat of GESAMP. In July 2013 WG-40 completed a draft assessment report, covering "the inputs of plastics and micro-plastics into the ocean, from land- and seabased human activities; the mechanisms and rates of particle degradation and fragmentation; the processes controlling particle transport and accumulation; the interaction of micro-plastics with organisms, and potential physical and chemical impacts; and public perceptions about marine litter in general and micro-plastics in particular." The final global assessment report on micro-plastics in the ocean was presented at the 2nd International Ocean Research Conference in Barcelona, Spain, in November 2014. 
EU

Marine litter is not addressed in the Water Framework Directive (WFD). Therefore, the management of marine litter in both coastal and open waters is defined by the Marine Strategy Framework Directive (MSFD) as described in the introduction to this chapter. The EU has also adopted the Honolulu Strategy mentioned above. In addition, to address specific waste challenges the Commission has proposed an aspirational target of reducing marine litter by $30 \%$ by 2020 for the ten most common types of litter found on beaches, as well as for fishing gear found at sea, with the list adapted to each of the four marine regions in the EU (EU 2014).

For providing technical recommendations for the implementation of the MSFD requirements with regard to monitoring and assessment of marine litter, the EC Directorate-General for the Environment has established a Technical Subgroup on Marine Litter (TSG ML). TSG ML has presented the outcome of their work in three reports (Galgani et al. 2010, 2011 \& 2013). The European Commission has also financed several projects dealing with different aspects of marine litter such as the projects Save the North Sea, MARLIN, CleanSea and MARLISCO.

\section{OSPAR}

The Oslo and Paris Commission (OSPAR) is the administrator of the OSPAR Convention protecting the marine environment of the North East Atlantic (incl. Kattegat) involving 15 contracting parties.

OSPAR has also established an expert group with regard to developing indicators and GES targets for MSFD in the Northeast Atlantic region (OSPAR 2012). OSPAR has also supported the development of EcoQO for ingestion of litter in fulmar, which has been recommended as an indicator for impact of marine litter for the North Atlantic region (OSPAR 2014).

In addition, OSPAR has been engaged in several activities concerning marine litter e.g. a pilot project on monitoring litter on beaches (including database), a project on monitoring litter at the sea, and publishing guidelines for implementation of "Fishing for Litter" projects (OSPAR 2007, 2009 \& 2010b).

OSPAR has developed a Regional Action Plan (RAP) for prevention and management of marine litter that was adopted in 2014 (OSPAR 2014b). The RAP includes implementation targets, but operational and reduction targets still have to be developed. The RAP will be implemented during 2012-2014, after which it will be reviewed and updated in accordance with the Quality Status Report 2012, the new OSPAR Strategy, and assessments under the Marine Strategy Framework Directive (MSFD). The effectiveness of the actions will be monitored and the implementations will be followed up nationally and reported every second year. 


\section{HELCOM}

The Helsinki Commission (HELCOM) is the administrator of the Helsinki Convention protecting the marine environment of the Baltic Sea area (incl. Kattegat) involving 10 contracting parties. HELCOM has not been engaged in many activities concerning marine litter, but the HELCOM Baltic Sea Action Plan (BSAP) includes an agreement to raise awareness of the negative environmental and economic effects of marine litter. Further, HELCOM has together with UNEP produced a report giving an overview of marine litter in the Baltic Region, and marine litter is highlighted in the latest status report as a potential problem (HELCOM 2007 \& 2010). With the recent HELCOM Copenhagen Ministerial Declaration (2013) it was decided to develop a Regional Action Plan (RAP) by 2015 at the latest with the aim of achieving a significant quantitative reduction of marine litter by 2025 , compared to 2015 , and to prevent harm to the coastal and marine environment.

The RAP will present concrete national and regional measures for prevention and reduction of marine litter from its main sources, develop common indicators and associated targets and identify socio-economic and biological impacts of marine litter. Two marine litter workshops have been organised in 2014 and a draft version of the RAP has been produced that after a national consultation will be finalised for expected adoption in March 2015 (HELCOM 2014).

\section{ICES}

The International Council for the Exploration of the Sea (ICES) is a nonpolitical global organization that works for enhanced ocean sustainability with a main focus on fisheries. ICES has since 2011 been involved in the development of technical recommendations for the monitoring of marine litter (Galgani et al. 2010, 2013). The ICES database has a format, which can contain data for other relevant marine litter indicators, e.g. data collected for litter captured in trawls during trawl surveys. Several ICES expert groups, e.g. MCWG, WGBEC, WGFAO, have also had environmental issues related to marine litter on the agenda in the recent years.

\section{IMO}

The International Maritime Organization (IMO) is a specialized agency of the United Nations (UN) that deals with safety and security of shipping and the prevention of marine pollution by ships. Part of the pollution from shipping is from dumping of waste material at sea, which is regulated by the London Convention and the International Convention for the Prevention of Pollution from Ships (MARPOL) both adopted by IMO. IMO has with the MARPOL convention, Annex V on Prevention of Pollu- 
tion by Garbage from Ships, totally prohibited the disposal of plastics anywhere into the sea, and severely restricts discharges of other garbage from ships into coastal waters and "Special Areas", which includes the Baltic Sea and the North Sea (IMO 2013). The Annex also obliges Governments to ensure the provision of reception facilities at ports and terminals for the reception of garbage in these areas. More recently, Resolution 60/30 of the United Nations (UN) invited IMO to review Annex $V$ of the MARPOL Protocol with the aim to assess its effectiveness in addressing sea-based sources of garbage. The review was completed and amendments to Annex V were adopted in July 2011. The new provisions under Annex V prohibit the disposal of all litter at sea unless stated otherwise. Consequently, ships will be required to send their litter to reception facilities at ports or inshore.

Figure 4.1. Port reception facilities, where ship-generated garbage easy can be sorted into adequate waste fractions are important element in the MARPOL convention aiming at reducing littering at sea

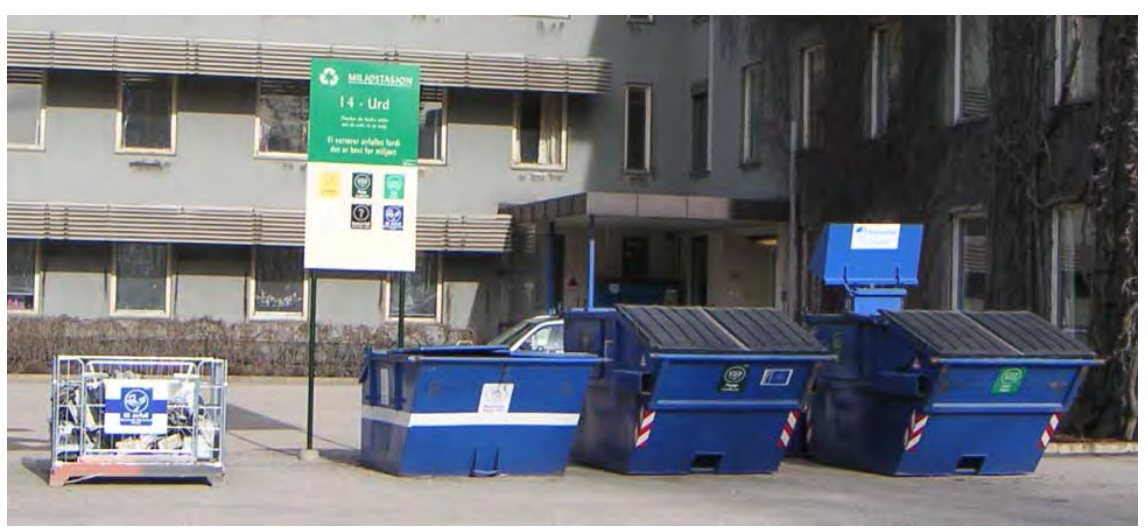

Photo: Jakob Strand, Grenland Harbor, Norway, 2005.

\section{NCM}

The Marine Group (HAV) within the Nordic Council of Ministers (NCM) has since 2013 prioritised environmental aspects of Marine litter in the Nordic waters and supported projects like:

- Plastic loading in Northern Fulmars, to gather new knowledge and to assess pollution levels of fulmars from Faroe Islands, Iceland and Svalbard, and also to focus on harmful effects resulting from the possible uptake of chemicals from plastics.

- The importance of sewage treatment plants as sources of marine microlitter in Finland, Sweden and Iceland, to investigate the waste 
water treatment plants as a gateway for microlitter to the environment and to investigate the presence of microliter in the recipient, gathering knowledge for assessing impact on recipient biota.

- Marine litter and its sources in Nordic waters, a project related to ongoing clean-up activities in Finland, Sweden, Denmark and Norway.

- Marine litter in Nordic waters (project of the present report).

- Icelandic conference on plastics. The short description of the conference is given on the page 54 in this report.

\section{KIMO}

Kommunernes Internationale Miljøorganisation (KIMO) is an international organization representing local municipalities that work to protect and enhance northern Europe's marine environment. KIMO coordinates the project "Fishing for Litter" the aim of which is to bring ashore litter gathered in nets during fishing. KIMO has also been involved in a study of microplastic in Swedish coastal waters.

\section{NGO'S}

Non-Governmental and related Organizations (NGO's) play a very significant role in creating awareness of marine litter e.g. by being involved in initiatives like beach clean-ups and other campaigns.

Despite the many initiatives in the Nordic countries and internationally there is still a general lack of knowledge about marine litter (Galgani et al. 2013). This concerns all relevant aspects, i.e. amounts, composition, spatial distribution, temporal trends, and the potential harmful biological, physical, and chemical impacts on marine life and human health of marine litter. The gaps in knowledge are a constraint in identifying baseline as well as targets and effective measures to reduce marine litter pollution. Accordingly, there is a need for research that can link quantities of litter and associated harm in the context of good environmental status (GES). But there is also a need for common, comparable, and quality assured monitoring tools for marine litter and harmonized recommendations and guidelines to assess GES at regional, national, and European scales. Furthermore, there is a need for international databases that can store the various types of marine litter data and ensure its quality, so that data for marine litter can be available for wider assessments. 



\section{Conclusions}

There have been and are currently several on-going projects, studying various aspect of pollution with marine litter in the Nordic waters that demonstrate ubiquitous occurrence of marine litter, including microplastics, at beaches, in the water column, on the sea floor, and in biota in the sea today. Studies on amounts, composition and other relevant properties and impact of marine litter have been performed in most Nordic sea regions covering both Baltic Sea, Skagerrak-Kattegat, North Sea, North Atlantic as well as the Arctic (although often using different types of measurements), which have potential for being used as environmental indicators, see Table 5.1. Several of these indicators have also been proposed as indicators for national monitoring programmes in the coming years.

\begin{tabular}{|c|c|c|c|}
\hline Marine litter indicators & Baltic Sea and Belt Sea & $\begin{array}{l}\text { North Sea, Skagerrak and } \\
\text { Kattegat }\end{array}$ & North Atlantic and Arctic \\
\hline \multicolumn{4}{|l|}{ Macro-litter } \\
\hline Beaches & $D K, F I, S E$ & $D K, N O, S E$ & $N O, I S, F O$ \\
\hline Water column & - & - & - \\
\hline Sea floor & $D K, S E$ & $D K, \mathrm{NO}, S E$ & NO, FO \\
\hline Biota & - & $\mathrm{DK}, \mathrm{NO}, \mathrm{SE}$ & $N O, F O, G L, I S$ \\
\hline \multicolumn{4}{|l|}{ Micro-litter } \\
\hline Beaches & - & $\mathrm{DK}, \mathrm{SE}$ & IS \\
\hline Water column & $\mathrm{Fl}, \mathrm{SE}$ & $\mathrm{NO}, S E$ & - \\
\hline Sediments & $D K$ & $D K, \mathrm{SE}$ & - \\
\hline Biota & $D K$ & SE & - \\
\hline
\end{tabular}

Countries: Denmark (DK), Norway (NO), Faroe Islands (FO), Finland (FI), Iceland (IS), Greenland (GL) and Sweden (SE).

These studies provide evidence that marine litter is a highly relevant environmental issue in Nordic waters and especially in areas that serve as final destinations for huge amounts of litter from other countries and sea regions. 
Although the same indicators have been used in different surveys, the results are not always fully comparable as different methodologies for sampling and analyses have been employed. The indicators for beach litter and stomach contents in the seabird northern fulmar for litter in biota, which both have been used for monitoring for more than 10 years, seem at the moment to be most developed indicators for regional comparisons. They have at the moment the most well-defined methodologies, although minor discrepancies might exist between the exact protocols used in different surveys. The results of these studies support the conclusion that both local land- and sea-based activities, as well as long-range transport of marine litter are important sources of the marine litter in Nordic seas. In particular, the beach litter data (for $100 \mathrm{~m}$ stretches) indicate that marine litter transported with ocean currents from other sea regions are an important external source for especially the eastern North Sea, Skagerrak and the some parts of the Arctic, e.g. at Svalbard.

This also shows that marine litter is a transnational problem. It is therefore important that the Nordic countries also are involved in management actions actively combatting marine litter pollution, both nationally and internationally, i.e. within the frames of EU, regional sea conventions and UN. It is also essential that cooperation and the building of scientific networks continue to be supported in the Nordic region.

For other marine litter indicators than beach litter and plastic ingestion by fulmar (see table 5.2), there is still a need to find out to what extent methodologies used in different surveys in the Nordic countries can produce comparable datasets, if needed. One of the overall targets in the MSFD, the regional seas actions plans and the national management plans for the marine litter indicators is to achieve significant decreasing temporal trends of marine litter in the coming years, and this can be assessed independently of the specific methodology as long as the continuous reported measurements, i.e. monitoring, is based on a well-defined methodology performed in the same sampling sites. Thereby, most of the data reported on different types of marine litter indicators can provide a good basis for prioritisation of activities regarding marine litter indicators for MSFD monitoring and national management plans in the Nordic countries. 
Table 5.2. Summary table of the methodologies employed in the Nordic countries for the reported marine litter indicators

\begin{tabular}{|c|c|}
\hline Marine litter indicators & Methodologies \\
\hline \multicolumn{2}{|l|}{ Macro-litter } \\
\hline Beaches & $\begin{array}{l}\text { Surveys at } 100 \mathrm{~m} \text { and } 1 \mathrm{~km} \text { stretches according to OSPAR, UNEP or EU monitoring } \\
\text { guidelines } \\
\text { In addition, various public clean-up activitie }\end{array}$ \\
\hline Water column & No studies reported \\
\hline Sea floor & $\begin{array}{l}\text { Trawl surveys (BITS, IBTS) } \\
\text { ROV video transects } \\
\text { Manned submersible } \\
\text { "Fishing for litter" } \\
\text { Retrieval of lost fishing nets }\end{array}$ \\
\hline Biota & $\begin{array}{l}\text { Plastic ingestion by seabirds like fulmars } \\
\text { Plastic as nest material for seabirds like kittiwake } \\
\text { Entanglement of seabirds like gannets } \\
\text { Entanglement of fish and crustaceans in ghost nets }\end{array}$ \\
\hline \multicolumn{2}{|l|}{ Micro-litter } \\
\hline & $\begin{array}{l}\text { Water column (manta-trawl, filter pump) } \\
\text { Beach sand/Tidal sediments } \\
\text { Sub-tidal sediments } \\
\text { Biota (Benthic invertebrates and fish }\end{array}$ \\
\hline
\end{tabular}

The complexity of the issues related to the monitoring and actions for combatting the marine litter makes it clear that it requires interdisciplinary approach for improvement of environmental assessment, source identification and solutions development to the problem. Thus it is necessary to continue collaboration involving different actors, i.e. industry, environmental managers, researchers, civil societal organisations, into the process of action plans development.

It is clear that both, the increasing trends in the marine litter and its negative effects onto the marine environment make this subject an important environmental issue, also for the coming years. The priority needs therefore still to be given to further developments of tools that can improve our understanding of the occurrence, trends and impact of litter in the aquatic environments as well as initiation of actions that are focused on the preventive measures, e.g. marine litter sources identification, societal attitudes change towards garbage discharges to the oceans, etc. 



\section{References}

Agersnap S. 2013. Mikroplastik i havmiljøet, metode til kvantificering af mikroplastik i havvand, blåmusling og fisk, student report from Aarhus University, Denmark, 28pp.

Anon 2008. Directive 2008/56/EC of the European parliament and of the council of 17 June 2008 establishing a framework for community action in the field of marine environment policy (Marine Strategy Framework Directive). Official Journal of the European Union L 164/19-40.

Anon 2010. Commission decision of 1 September 2010 on criteria and methodological standards on good environmental status of marine waters. Official Journal of the European Union L 232/14-24.

Aniansson B. et al. 2007. OSPAR Pilot Project on Monitoring Marine Beach Litter. Monitoring of marine litter in the OSPAR region. Biodiversity Series.

Anker-Nilssen T. 2014. Plastikkpartikler i havhester som strander i Sørvest-Norge, Indicator fact sheet from Norwegian Institute for Nature Research (NINA).

Bergmann M., \& Klages M. 2012. Increase of litter at the Arctic deep-sea observatory HAUSGARTEN. Marine Pollution Bulletin, 64(12), 2734-41.

doi:10.1016/j.marpolbul.2012.09.018

Browne et al. 2004.

Cheshire A., \& Adler E. 2009. UNEP/IOC Guidelines on Survey and Monitoring of Marine Litter. Regional Seas Reports and Studies No. 186 IOC Technical Series No. 83.

Claessens M., De Meester S., Van Landuyt L., De Clerck K. \& Janssen C.R., 2011. Occurrence and distribution of microplastics in marine sediments along the Belgian coast. Marine Pollution Bulletin 62, 2199-2204.

Claessens M., Van Cauwenberghe L., Vandegehuchte, M.B. \& Janssen C.R., 2013. New techniques for the detection of microplastics in sediments and field collected organisms. Marine Pollution Bulletin 70, 227-233.

Cole M., Lindeque P., Fileman E., Halsband C., Goodhead R., Moger J., \& Galloway T. S. 2013. Microplastic ingestion by zooplankton. Environmental Science \& Technology, 47(12), 6646-55. doi:10.1021/es400663f

de Haas H., van Weering T.C.E., de Stigter H. (2002). Organic carbon in shelf seas: sinks or sources, processes and products. Continental Shelf Research Volume 22(5): 691-717

Derksen D. M., Kindermann O., Schweikart A., \& Steinecke K. 2012. Belastung mariner Lebensräume durch Mikroplastik: Stand der Wissenschaft sowie erste Ergebnisse einer Vorstudie zur Erfassung und Bewertung des Vorkommens von Mikroplastik- granulat im Sediment von Küsten der deutschen Nordsee. Bremer Beiträge Zur Geographie U. Raumplanung, 44, 96-107.

Derraik J. G. B. 2002. The pollution of the marine environment by plastic debris: a review. Marine Pollution Bulletin, 44, 842-852.

Dippo B.M., 2012. Microplastics in the coastal environment of west Iceland. Faculty of Buiness and Science. University of Akureyri, p. 66. 
Falk K., Durinck J., 1993. The winter diet of thick-billed murres, Uria lomvia, in Western Greenland, 1988-1989. Rev. Can. Zool. 71, 264-272.

Eisma D. \& Kalf J. 1987. Dispersal, concentration and deposition of suspended matter in the North Sea. Journal of the Geological Society 144:161-178.

Eklund B., Elfström M., Borg H. (2008). Tributyltin Originates from Pleasure Boats in Sweden in Spite of Firm Restrictions. Open Environmental Sciences, 2: 124-132

Eriksen, M., Mason, S., Wilson, S., Boxa, C., Zellers, A., Edwards, W., Farley, H. \& Amatoa, S., 2013. Microplastic pollution in the surface waters of the Laurentian Great Lakes. Marine Pollution Bulletin in press.

European Commission. 2008. DIRECTIVE 2008/56/EC OF THE EUROPEAN PARLIAMENT AND OF THE COUNCIL of 17 June 2008 establishing a framework for community action in the field of marine environmental policy (Marine Strategy Framework Directive).

European Commission. 2010. COMMISSION DECISION of 1 September 2010 on criteria and methodological standards on good environmental status of marine waters (notified under document C (2010) 5956) (2010/477/EU).

European Commission. 2014. COMMUNICATION FROM THE COMMISSION TO THE EUROPEAN PARLIAMENT, THE COUNCIL, THE EUROPEAN ECONOMIC AND SOCIAL COMMITTEE AND THE COMMITTEE OF THE REGIONS. Towards a circular economy: A zero waste programme for Europe. (COM(2014) 398 final).

Farrell P., \& Nelson K. 2013. Trophic level transfer of microplastic: Mytilus edulis (L.) to Carcinus maenas (L.). Environmental Pollution (Barking, Essex : 1987), 177, 1-3. doi:10.1016/j.envpol.2013.01.046

Fiskebåt 2012. Fiskebåt støtter "Fishing-for-litter". http://www.fiskebat.no/ default.asp?page $=9321,5167$ \&lang $=1 \&$ item $=53596,1$

Fleet D., van Franeker J., Dagevos J., Hougee M. (2009). Marine Litter. Wadden Sea Ecosystem No. 25, Thematic Report No. 3.8 for the Quality Status Report 2009, Trilateral Monitoring and Assessment Group (TMAG).

Foekema, E.M., De Gruijter, C., Mergia, M.T., van Franeker, J.A., Murk, A.T.J. \& Koelmans, A.A., 2013. Plastic in North Sea fish. Environmental Science and Technology $47,8818-8824$.

Gabrielsen G.W. Et hav af søppel. Kronikk 3. september 2013 I Adresseavisen, Norge, http://www.adressa.no/meninger/kronikker/article8209545.ece

Galgani F., Fleet D., van Franeker J., et al. 2010. Marine Strategy Framework Directive Task Group 10 Report Marine litter, JRC Scientific and Technical Report, ICES/JRC/ IFREMER Joint Report (No. 31210-2009/2010), Ed. by N. Zampoukas. 57 pp.

Galgani F., Hanke G, Werner S.,\& Piha H. (2011). MSFD GES Technical Subgroup on Marine Litter. Technical Recommendations for the Implementation of MSFD Requirements. JRC Scientific and Technical Report, EUR 25009 EN - 2011. 93 pp.

Galgani F., Hanke G., Werner S., et al. (2013). Guidance on Monitoring of Marine Litter in European Seas. MSFD GES Technical Subgroup on Marine Litter (TSG-ML).

Gregory M.R. 2009. Environmental implications of plastic debris in marine settingsentanglement, ingestion, smothering, hangers-on, hitch-hiking and alien invasions. Phil. Trans. R. Soc. B 364: 2013-2025.

Hidalgo-Ruz V., Gutow L., Thompson R. C., \& Thiel M. 2012. Microplastics in the marine environment: a review of the methods used for identification and quantification. Environmental Science \& Technology, 46(6), 3060-75. doi:10.1021/es2031505.

Gilman N.E., 2013. Examining spatial concentrations of marine micro-plastics on shorelines in South Pudget Sound, Washington. The Evergreen State College, p. 101. 
Hartwig E., Clemens T., Heckroth M. 2007. Plastic debris as nesting material in a Kittiwake-(Rissa tridactyla)-colony at the Jammerbugt, Northwest Denmark. Marine Pollution Bulletin 54: 595-597.

HELCOM 2007. Marine litter in the Baltic Sea region: Assessment of the Marine Litter problem in the Baltic region and priorities for response, Baltic Marine Environment Protection Commission. 21 pp.

HELCOM 2010. Ecosystem health of the Baltic Sea 2003-2007: HELCOM initial holistic assessment. Balt. Sea Environ. Proc. No. 122, 63 pp.

HELCOM Copenhagen Ministerial Declaration (2013). Taking Further Action to Implement the Baltic Sea Action Plan - Reaching Good Environmental Status for a healthy Baltic Sea. 19 pp.

HELCOM 2014. HELCOM Regional Action Plan on marine litter (RAP ML), draft presented at 2nd Nordic workshop "Marine litter - monitoring and management in the Nordic context", 6-7 November 2014.

HELCOM CORESET 2014. Outcome of the second workshop of the project operationalization of HELCOM core indicators (CORESET II 2-2014), Gothenburg, Sweden, 29-30 September 2014.

Hoellein T., Rojas M., Pink A., Gasior J., Kelly J. (2014) Anthropogenic Litter in Urban Freshwater Ecosystems: Distribution and Microbial Interactions. PLoS ONE 9(6): e98485. doi:10.1371/journal.pone.0098485.

MARLIN 2013. Final Report of Baltic Marine Litter Project MARLIN - Litter Monitoring and Raising Awareness. Appendix 2 UNEP Guidelines Translated to Baltic Sea Conditions. Online August 2014.

Jartun M., Ottesen R.T., Steinnes E., Volden T. (2009). Painted surfaces - Important sources of polychlorinated biphenyls (PCBs) contamination to the urban and marine environment, Environmental Pollution 157 295-302.

JRC Scientific and Technical Reports. (2011). Marine Litter. Technical Recommendations for the Implementation of MSFD Requirements. MSFD GES Technical Subgroup on Marine Litter. doi:10.2788/92438.

Johansson A., 2011. Mikroskopiska antropogena partiklar i marina sediment. Göteborgs universitet, p. 37.

KIMO 2013. Fishing for litter, http://www.kimointernational.org/FishingforLitter.aspx

KLIF 2011. Kunnskap om marint søppel i Norge 2010. Report from Klima- og Forurensningsdirektoratet and Direktoratet for Naturforvaltning, TA-2753. 33 pp.

Kühn S., \& van Franeker J. a. 2012. Plastic ingestion by the northern fulmar (Fulmarus glacialis) in Iceland. Marine Pollution Bulletin, 64(6), 1252-4.

doi:10.1016/j.marpolbul.2012.02.027.

Lattin G.L., Moore C.J., Zellers A.F., Moore S.L. \& Weisberg S.B., 2004. A comparison of neustonic plastic and zooplankton at different depths near the southern California shore. Marine Pollution Bulletin 49, 291-294.

Law K.L., Morét-Ferguson S., Maximenko N.A., Proskurowski G., Peacock E.E., Hafner J. \& Reddy, C.M., 2010. Plastic accumulation in the North Atlantic Subtropical Gyre. Science $329,1185-1188$.

Leslie H.A., van der Meulen M.D., Kleissen F.M. \& Vethaak A.D., 2011. Microplastic litter in the Dutch Marine Environment. In: Deltares, N. (Ed.). IVM Institute for Environmental Studies, p. 97.

Magnusson K. \& Norén F., 2011. Mikroskopiskt skräp i havet - metodutveckling för miljöövervakning. In: Rapport till Naturvårdsverket (Ed.). Swedish Environmental Protection Agency, p. 22. 
Magnusson K. 2014. Micro-litter and other microscopic anthropogenic particles in the sea area off Rauma at Turku, Finland. Report from the swedish Environmental research Institute. 18pp.

Magnusson K. \& Wahlberg C. (2014). Mikroskopiske skräppartiklar I vatten from avloppsreningsverk. Report No. B2208 from Swedish Environmental Research Institute, 33pp.

Maes T. \& Garnacho E. 2013. Summary of current methods of monitoring and assessment for marine litter. Deliverable D1.2 report. MARLISCO project. MARine Litter in Europe Seas: Social AwareneS and CO-Reponsibility. (EC FP7 Coordinated and support action, SIS-MML-289042), July 2013. 25pp.

Mehlhart G., Blepp M. 2012). Study on land-based sourced litter (LSL) in the marine environment. Review of sources and literature In the Context of the Initiative of the Declaration of the Global Plastics Associations for Solutions on Marine Litter. Report from the Öko-Institut e.V. - Institut für angewandte Ökologie, 128pp.

Murray F. \& Cowie, P. R. (2011). Plastic contamination in the decapod crustacean Nephrops norvegicus (Linnaeus, 1758). Marine Pollution Bulletin, 62(6), 1207-17. doi:10.1016/j.marpolbul.2011.03.032.

Negri A, Marshall P. (2009). TBT contamination of remote marine environments: Ship groundings andice-breakers as sources of organotins in the Great Barrier Reef and Antarctica. Journal of Environmental Management 90 S31-S40.

Norén F. 2010. Survey of microscopic anthropogenic particles in Skagerrak. Pilot study October-November 2010 Norwegian Climate and Pollution Agency (KLIF), p. 19.

Norden Andersen O.G. (1978). Elastic band pollution and its sublethal effects upon fish. Biokon. Rep. 7.1-8.

Norwegian Directorate of Fisheries, 2011). Opprenskning av tapte fiskeredskap 2011. Rapport fra Fiskeridirektoratet (http://www.fiskeridir.no).

Norwegian Directorate of Fisheries (2013). Opprenskning av tapte fiskeredskap 2013. Rapport fra Fiskeridirektoratet (http://www.fiskeridir.no).

NST 2012a:Basisanalyse til brug for Danmarks Havstrategi. Miljøministeriet, Naturstyrelsen. $100 \mathrm{pp}$.

NST 2012b: Miljømålsrapport til brug for Danmarks Havstrategi. Miljøministeriet, Naturstyrelsen. 30 pp.

Obbard R.W, Sadri S., Ying Qi Wong Y.Q., Khitun A.A., Baker I., Thompson R.C. 2014. Global warming releases microplastic legacy frozen in Arctic Sea ice. Earth's Future 2(6):315-320.

OSPAR 2007. OSPAR Pilot Project on Monitoring Marine Beach Litter - Monitoring of marine litter in the OSPAR region. OSPAR report 386. 74 pp.

OSPAR 2009. Marine litter in the North-East Atlantic Region: assessment and priorities for response. London, United Kingdom. 127 pp.

OSPAR 2010: Quality Status Report 2010. OSPAR Commission. 176 pp.

OSPAR 2010b. OSPAR Recommendation 2010/19 on the reduction of marine litter through the implementation of fishing for litter initiatives. OSPAR 10/23/1-E, Annex 47.

OSPAR 2012. MSFD Advice document on Good environmental status - Descriptor 10: Marine Litter. A living document - Version of 17 January 2012, Biodiversity Series, Prepared by the Intercorrespondence Group on Marine Litter of the OSPAR Committee of the Environmental Impact of Human Activities (EIHA), 9pp.

OSPAR 2014a. Litter in the Marine Environment - Plastic Particles in Fulmar Stomachs - 2014. OSPAR indicator fact sheet EIHA14/AS02. 
OSPAR 2014b. Regional Action Plan for Prevention and Management of Marine Litter in the North-East Atlantic, OSPAR Agreement 2014-1.

Provencher et al. (2009). Evidence for increased ingestion of plastics by northern fulmars (Fulmarus glacialis) in the Canadian Arctic. Marine Pollution Bulletin 58(7):1092-1095.

Provencher et al. (2014). Prevalence of marine debris in marine birds from the North Atlantic. Marine Pollution Bulletin 84: 411-417.

Rochman, C. M., Browne, M. A., Halpern, et al. (2013). Policy: Classify plastic waste as hazardous. Nature, 494(7436), 169-71. doi:10.1038/494169a.

Setälä O., Fleming-Lehtinen V. \& Lehtiniemi M., 2014. Ingestion and transfer of microplastics in the planktonic food web. Environmental Pollution 185, 77-83.

Skóra M. E., Sapota M. R., Skóra K. E. \& Pawelec A. 2012. Diet of the twaite shad Alosa fallax (Lacépède, 1803) (Clupeidae) in the Gulf of Gdansk, the Baltic Sea. Oceanological and Hydrobiological Studies, 41(3), 24-32. doi:10.2478/s13545-012-0024-0.

Strand et al. (in prep). Occurrence of microplastic particles and bio-geochemical relationships in sediments from Danish waters. Poster presented at 2 nd Nordic workshop "Marine litter - monitoring and management in the Nordic context", 6-7 November 2014.

SwAM 2012. God havsmiljö 2020 - Marin strategi för Nordsjön och Östersjön. Del 1: Inledande bedömning av miljötilstånd och socioekonomisk analys. Havs- och vattenmyndighetens rapport 2012:19. 334 pp.

SwAM 2012b. God havsmiljö 2020 - Marin strategi för Nordsjön och Östersjön. Del 2: God miljöstatus och miljökvalitetsnormer. Havs- och vattenmyndighetens rapport 2012:20. 154 pp.

Sørensen T. K., Stedmon C., Enders K. \& Henriksen 0. 2013. Analyse af marint affald i sild og hvilling fra det nordlige Storebælt. Rapport udarbejdet til Naturstyrelsen. 12 p.

Tanaka K., Takada H., Yamashita R., Mizukawa K., Fukuwaka M., Watanuki Y. 2013. Accumulation of plastic-derived chemicals in tissues of seabirds ingesting marine plastics. Marine Pollution Bulletin 69: 219-222.

Thompson R.C., Olsen Y., Mitchell R.P., Davis A., Rowland S.J., John A.W.G., McGonigle D. \& Russell A.E., 2004. Lost at sea: Where is all the plastic? Science 304, 838.

Trevail A.M., Kühn S., Gabrielsen G.W., van Franeker J.A. 2014. Quantifying marine plastic litter in the European Arctic. Preliminary findings from Norwegian Polar Institute on plastic ingestion of fulmars from Svalbard, Norway. Poster presented at 2nd workshop "Marine litter - monitoring and management in the Nordic context", 6-7 November 2014.

Trouwborst A. 2011: Managing marine litter: Exploring the evolving role of international and European law in confronting a persistent environmental problem. Merkourios 27/73: 4-18.

UNEP 2005. Marine Litter. An analytical overview. United Nations Environment Programme.

UNEP 2009: Marine Litter: A Global Challenge. United Nations Environment Programme, Nairobi. $232 \mathrm{pp}$.

UNEP \& NOAA 2012. The Honolulu strategy. A global framework for prevention and management of marine debris. 57pp.

Van Cauwenberghe L., Claessens M., Vandegehuchte M. \& Janssen C.R., 2012. Occurrence of microplastics in mussels (Mytilus edulis) and lugworms (Arenicola marina) collected along the French-Belgian-Dutch coast. VLIZ Special Publication 55. 
Van Franeker J., Blaize C., Danielsen J., et al. 2011. Monitoring plastic ingestion by the northern fulmar Fulmarus glacialis in the North Sea. Environmental Pollution (Barking, Essex : 1987), 159(10), 2609-15. doi:10.1016/j.envpol.2011.06.008.

Von Moos N., Burkhardt-Holm P. \& Köhler A. 2012. Uptake and Effects of Microplastics on Cells and Tissue of the Blue Mussel Mytilus edulis L. after an Experimental Exposure. Environmental Science \& Technology, 46, 11327-11335.

Wright S. L., Thompson R. C. \& Galloway T. S. 2013. The physical impacts of microplastics on marine organisms: a review. Environmental Pollution (Barking, Essex : 1987), 178, 483-92. doi:10.1016/j.envpol.2013.02.031.

Zettler E.R., Mincer T.J., Amaral-Zettler L.A. 2013. Life in the "Plastisphere": Microbial Communities on Plastic Marine Debris. Environmental Science \& Technology 47 (13): 7137-7146. 


\section{Sammenfatning}

I de senere år har der været øget fokus på de miljømæssige problemer af marint affald, efter at en række undersøgelser har beskrevet, at der på global skala forekommer store mængder af affald bestående af plast og andre syntetiske materialer i havene. Internationale institutioner som EU, OSPAR, HELCOM og FN har identificeret affald i havet som et vigtigt område, som bør prioriteres både i form af videnopbygning og udvikling af miljø-indikatorer, der kan bruges til at vurdere omfanget af belastningen og de effekter, som affaldet har i havmiljøet. I Europa er marint affald nu højt på den miljømæssige dagsorden, især efter at EU's Havstrategidirektiv er blevet implementeret. Havstrategidirektivet forpligter EU's medlemslande til at udvikle og fastsætte miljømål og dertilhørende indikatorer for marint affald og igangsætte andre tiltag for at værne om havmiljøet. Dette har medvirket til, at miljøproblemer med affald i havet også har fået stigende opmærksomhed i de nordiske lande.

I de nordiske lande har der været og er forsat en række igangværende feltundersøgelser omkring forekomst og effekter af affald i havet, som er udført i regi af forskningsprojekter, overvågning og andre typer af undersøgelser. Disse undersøgelser understøtter, at forekomsten af affald er allestedsværende i nordisk havmiljø, dvs. både i Østersøen, Nordsøen og Nordatlanten samt i Arktis. I disse områder kan affald findes både på strande, i vandsøjlen (inkl. havis), på og i havbunden og i de marine fødekæder (biota).

Denne rapport giver et overblik over de tilgængelige data fra undersøgelser af marint affald i de nordiske farvande. Disse data stammer fra forskellige feltstudier af mængder, udbredelse, sammensætning og påvirkninger af både større stykker affald og af mikroskopiske partikler. Derved kan de rapporterede data bruges som input til den fortsatte prioritering af nationale aktiviteter, især med henblik på etablering af miljømål og dertilhørende indikatorer for marint affald, som er relevante for overvågning og miljøvurderinger i forbindelse med udmøntningen af EU's havstrategidirektiv og de nationale forvaltningsplaner i de nordiske lande. Det bør dog også bemærkes, at resultaterne fra de forskellige nordiske undersøgelser ikke altid er sammenlignelige, da forskellige metoder er blevet anvendt til prøvetagning og analyser. Der er derfor behov for en fortsat fælles opsamling af viden og erfaringer og standar- 
disering af metoder med udgangspunkt i de regionale forhold for at sætte dette miljøproblem i et fælles nordisk perspektiv. Denne rapport indeholder oplysninger, der kan bruges som et bidrag til denne proces. 


\section{Workshop 1 Programme and participants}

Expert workshop on Marine Litter in the Nordic Countries - and indicators relevant for EU MSFD. Place: Kristineberg Marine Research Station (KMRS), Göteborg, Sweden. Date: 14th of November 2013.

\section{Workshop agenda}

1) Presentations from 2-3 key-note speakers (20 min each) on status for monitoring and assessment of Marine Strategy Framework Directive (MSFD) relevant indicators on marine litter (Descriptor 10), which will cover both:

- Macroscopic pieces of marine litter,

- Microplastic particles,

- Impact of marine litter on the marine organisms.

2) Short presentations from workshop participants (5-10 min each) on relevant activities in regard to research, monitoring and assessments on marine litter in the Nordic countries. These short presentations will function as the basis for further discussion on:

- Strengthening the research and monitoring network in Nordic countries on marine litter issues,

- Mapping the "litter-talents" in the Nordic countries: Building the interdisciplinary infrastructure in relation to the sampling, analytical and other capacities.

3) Group work/discussion on the main topics of the workshop:

- Status of the work on marine litter in the Nordic countries.

- Evaluation of the MSFD indicators for marine litter relevant for monitoring and assessment in the Nordic countries. 
- The advantages and disadvantages for the application of common indicators for the MSFD.

4) Provide first recommendations on (common?) monitoring strategies of marine litter in the Nordic countries.

\section{Participants of the Expert workshop on Marine Litter in the Nordic Countries - and indicators} relevant for EU MSFD

\begin{tabular}{|c|c|c|}
\hline Country & Name & Organisation, adresse \\
\hline Denmark & Thomas Kirk Sørensen & Technical University of Denmark (DTU Aqua) \\
\hline Denmark & Jakob Strand & Aarhus University \\
\hline Denmark & Jens Wurgler Hansen & Aarhus University \\
\hline Denmark & Zhanna Tairova & Aarhus University \\
\hline Sweden & Jessica Ångström & The Keep Sweden Tidy Foundation \\
\hline Sweden & Kerstin Magnusson & Swedish Environemental Research Institute (IVL) \\
\hline Sweden & Fredrik Noren & Swedish Environemental Research Institute (IVL) \\
\hline Norway & Runar Mathisen & Norwegian Environmental Agency \\
\hline Norway & Kevin Thomas & NIVA Norway \\
\hline Norway & Lars Johan Naustvoll & Institute of Marine Research (IMR) \\
\hline Faroe Islands/Sweden & Johannis Danielsen & Faroe Marine Research Institute (FMRI) \\
\hline Finland & Outi Setälä & SYKE Marine Research Centre \\
\hline Germany & Nicolai Fricke & Federal Research Institute for Rural Areas, Forestry and Fisheries (Thünen) \\
\hline UK & Thomas Maes & Centre for Environment, Fisheries and Aquaculture Science (CEFAS) \\
\hline
\end{tabular}




\section{Workshop 2 Programme and participants}

Workshop "Marine litter - monitoring and management in the Nordic context." Place: Conference Center of the Norwegian Environment Agency, Strømsveien 96, Oslo. Date: 6-7 November 2014.

Workshop aimed to create a platform/forum for the national environmental authorities and other stakeholders (NGO's, industry, etc.) in Nordic countries, for the discussions on the following topics:

- Current status on: 1) Facts and awareness on marine litter (ML) issues in a Nordic perspective; 2) How far have national management plans and monitoring for ML developed in relation to implementation of Marine Strategy Framework Directive (MSFD) and regional action plans (RAP) produced by OSPAR and HELCOM.

- Collaboration between three main actors on establishing a better knowledge and data transfer, together with action planning between the relevant main actors: scientific communities, environmental managers and society (civil societal organization, NGO's, industry, etc.) in order to cover different relevant indicators for marine litter, like beach surveys, fulmar ingestion, fishery impact, socio-economic impact, source identification, and measures in the Nordic countries.

- Regional Action Plans (RAP) - which actions and measures are the most important, effective and realistic for combatting marine litter. 
Participants of the workshop “Marine litter - monitoring and management in the Nordic context"

\begin{tabular}{|c|c|c|}
\hline Country & Name & Organisation, adresse \\
\hline Denmark & Thomas Kirk Sørensen & Technical University of Denmark (DTU Aqua) \\
\hline Denmark & Ryan d'Arcy Metcalfe & KIMO Danmark \\
\hline Denmark & Helle Fabiansen & Plastindustrien \\
\hline Denmark & Claudia Sick & NGO “Plastic change” \\
\hline Denmark/Slovenia & Andreja Palatinus; Štefan Trdan & EEA (EEA, Institute for Water of the Republic of Slovenia) \\
\hline Denmark & Robin Lenz; Kristina Enders & Technical University of Denmark (DTU Aqua) \\
\hline Denmark & Jakob Strand & Aarhus University \\
\hline Denmark & Jens Wurgler Hansen & Aarhus University \\
\hline Denmark & Zhanna Tairova & Aarhus University \\
\hline Sweden & Jessica Ångström & The Keep Sweden Tidy Foundation \\
\hline Sweden & Kerstin Magnusson & Swedish Environemental Research Institute (IVL) \\
\hline Sweden & Johanna Eriksson & Havs- och vattenmyndigheten \\
\hline Sweden & Jessica Lundqvist & Göteborg University \\
\hline Sweden & Katja Broeg & Stockholm University \\
\hline Sweden & Martin Hassellöv & Göteborg Universitet \\
\hline Norway & Runar Mathisen & Norwegian Environmental Agency \\
\hline Norway & Erlend Standal & Norwegian Environmental Agency \\
\hline Norway & Lars Johan & Havforskningsinstituttet \\
\hline Norway & Claudia Halsband & Akvaplan-NIVA in Troms $\varnothing$ \\
\hline Norway & Camilla Pettersen & Norwegian Environmental Agency \\
\hline Norway & Norith Habberstad Eckbo & Norwegian Environmental Agency \\
\hline Norway & Liv-Marit Hansen & Oslofjorden friluftsråd \\
\hline Norway & Peter Sundt & Mepex Consult AS \\
\hline Faroe Islands & Johannis Danielsen & Faroe Marine Research Institute (FMRI) \\
\hline Iceland & Helgi Jensson & Environment Agency of Iceland \\
\hline Iceland & Gudlaugur Sverrisson & Icelandic Recycling Fund \\
\hline UK & Thomas Maes & Centre for Environment, Fisheries and Aquaculture Science (CEFAS) \\
\hline UK & John Mouat & The OSPAR Commission Secretariat \\
\hline
\end{tabular}


Ved Stranden 18

DK-1061 Copenhagen K

www.norden.org

\section{Marine Litter in Nordic waters}

This report provides an overview of the currently available data from studies on marine litter in the Nordic countries. This covers various field studies on amount, distribution, characteristics and impact of macro- and micro-litter particles. The data reported can provide a good basis for prioritisation of activities, especially having the establishment of marine litter indicators for EU's Marine Strategy Framework Directive monitoring and national management plans in the Nordic countries in mind.

TemaNord 2015:521

ISBN 978-92-893-4030-4 (PRINT)

ISBN 978-92-893-4031-1 (PDF)

ISBN 978-92-893-4032-8 (EPUB)

ISSN 0908-6692
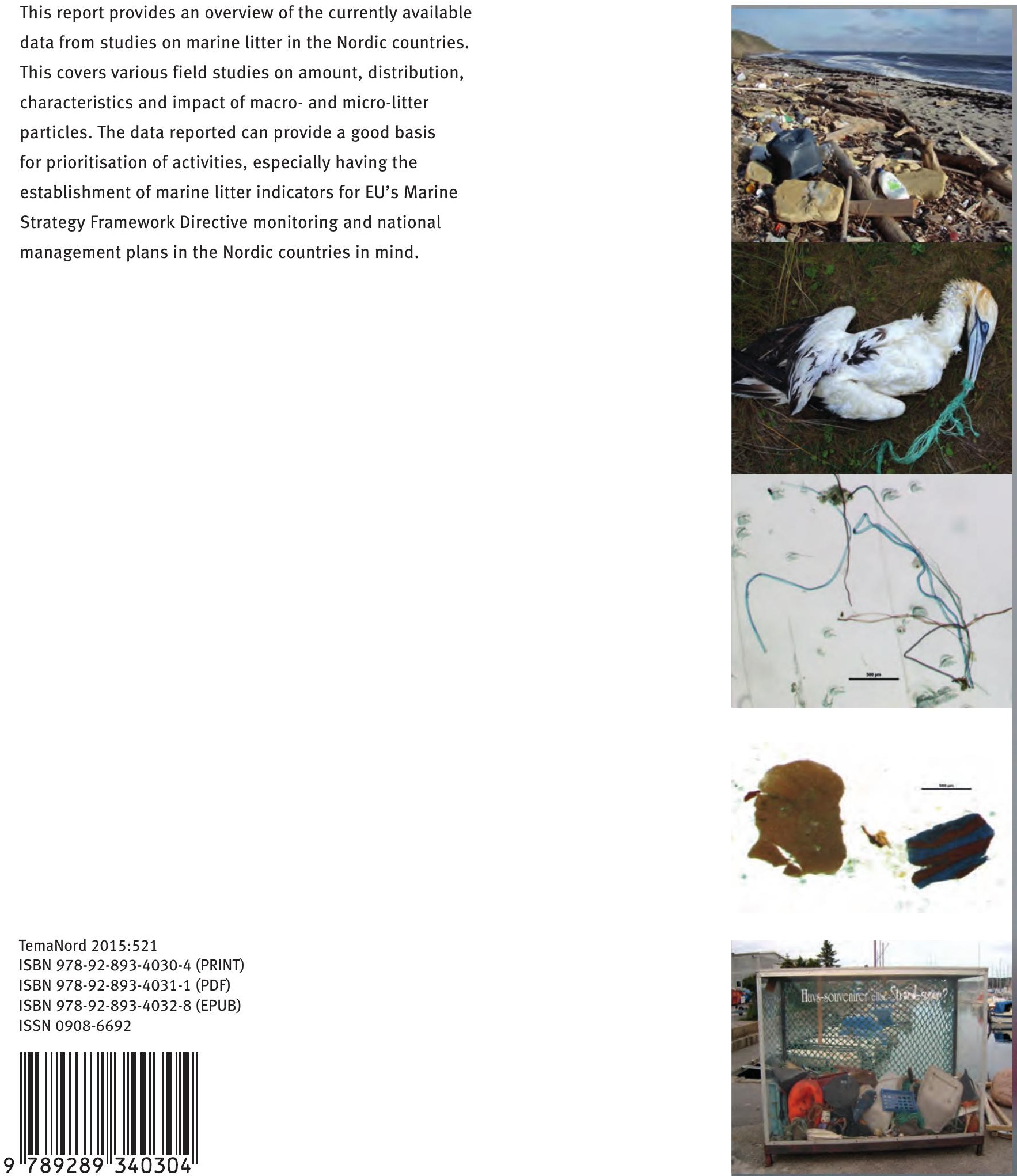